\title{
Targeting Hypoxia: Revival of Old Remedies
}

\author{
Nuria Vilaplana-Lopera, Maxym Besh and Eui Jung Moon * \\ Department of Oncology, MRC Oxford Institute for Radiation Oncology, University of Oxford, \\ Headington OX3 7DQ, UK; nuria.vilaplanalopera@oncology.ox.ac.uk (N.V.-L.); \\ maxym.besh@oncology.ox.ac.uk (M.B.) \\ * Correspondence: ejung.moon@oncology.ox.ac.uk
}

check for updates

Citation: Vilaplana-Lopera, N.; Besh, M.; Moon, E.J. Targeting Hypoxia: Revival of Old Remedies. Biomolecules 2021, 11, 1604. https://doi.org/ 10.3390/biom11111604

Academic Editors: Ruoli Chen,

Nicholas R. Forsyth and Christopher J. Schofield

Received: 1 October 2021

Accepted: 26 October 2021

Published: 29 October 2021

Publisher's Note: MDPI stays neutral with regard to jurisdictional claims in published maps and institutional affiliations.

Copyright: (c) 2021 by the authors. Licensee MDPI, Basel, Switzerland. This article is an open access article distributed under the terms and conditions of the Creative Commons Attribution (CC BY) license (https:// creativecommons.org/licenses/by/ $4.0 /)$.
Abstract: Tumour hypoxia is significantly correlated with patient survival and treatment outcomes. At the molecular level, hypoxia is a major driving factor for tumour progression and aggressiveness. Despite the accumulative scientific and clinical efforts to target hypoxia, there is still a need to find specific treatments for tumour hypoxia. In this review, we discuss a variety of approaches to alter the low oxygen tumour microenvironment or hypoxia pathways including carbogen breathing, hyperthermia, hypoxia-activated prodrugs, tumour metabolism and hypoxia-inducible factor (HIF) inhibitors. The recent advances in technology and biological understanding reveal the importance of revisiting old therapeutic regimens and repurposing their uses clinically.

Keywords: hypoxia; cancer; tirapazamine; hyperthermia; carbogen breathing; tumour metabolism

\section{Introduction}

The presence of low oxygen concentrations, known as hypoxia, is a prevalent characteristic of the microenvironment of solid tumours [1]. Tumour hypoxia causes aggressive tumour progression and treatment resistance, which leads to poor patient survival. Hypoxia arises from an imbalance between oxygen consumption and delivery, which is caused by rapid tumour cell proliferation and an inefficient blood supply carrying oxygen and nutrients [2]. In radiobiology, tumour hypoxia, which is defined as an oxygen tension below $10 \mathrm{mmHg}$, is significantly correlated with radiation resistance due to the role of oxygen in the "fixation" of DNA damage. In addition to direct DNA damage by single- or double-strand breaks (SSB or DSB), the ionizing radiation causes indirect DNA damage by producing free radicals that reinforce the damage and make it permanent. However, the reduced production of free radicals under hypoxic conditions allows for the repair of the radiation-induced damage before it is "fixed" [3]. The abnormal blood vessels in the tumour also contribute to tumour chemoresistance by impeding drug perfusion and delivery. Additionally, in hypoxia, slow cell proliferation rates, as well as the upregulation of drug resistance-related genes, intensify the resistance of tumour cells [4].

For over a century there have been consistent efforts to target tumour hypoxia to promote radiation and chemotherapy responses. However, due to technical challenges and/or the lack of understanding of tumour biology, most trials failed in the clinical setting. Therefore, there is still a strong demand to solve these unmet needs to alleviate tumour hypoxia. In this review, we focus on the historical approaches to targeting hypoxia and how these can be better applied in the current times, in combination with new advances in techniques and molecular targeted treatments. A summary of the approaches discussed in this review is depicted in Figure 1. 

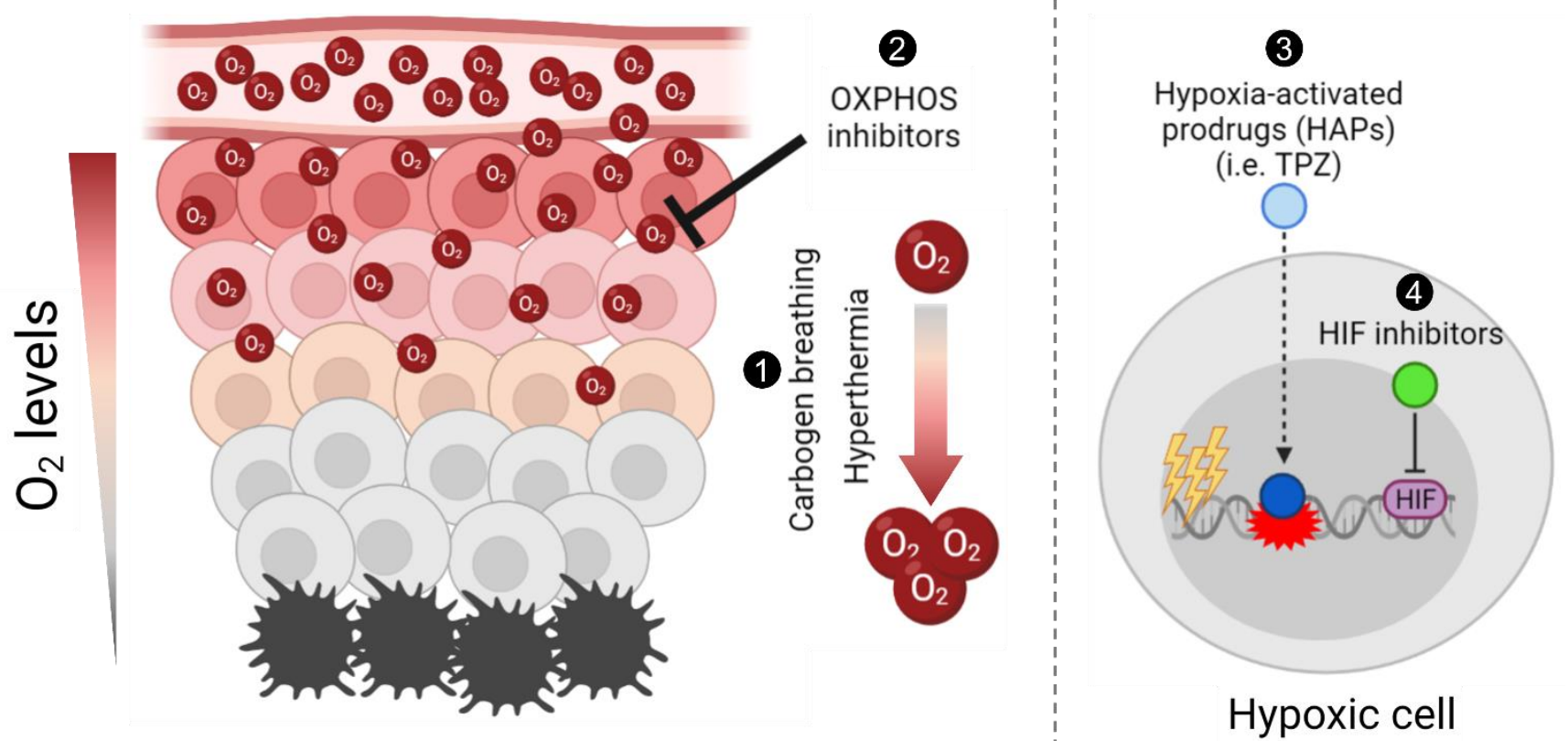

Figure 1. Schematic summary of different approaches to target tumour hypoxia. Briefly, (1) carbogen breathing and hyperthermia aim to increase the overall oxygen concentration in tumours, enhancing radiosensitisation; (2) Oxidative phosphorylation (OXPHOS) inhibitors target mitochondrial metabolism in well-oxygenated cells to promote an increase and diffusion of the overall oxygen into hypoxic regions and enhance radiation-induced damage; (3) hypoxia-activated prodrugs (HAPs), such as tirapazamine (TPZ), are reduced into their active cytotoxic form in hypoxic cells; and (4) the hypoxia-inducible factor (HIF) inhibitors aim to inhibit the hypoxia-induced activation of HIF, hence selectively targeting hypoxic cells. The figure was generated using Biorender.com (Accessed on 21 October 2021).

\section{Carbogen Breathing}

The most relevant approach to overcome tumour hypoxia is to promote oxygen delivery. Hyperbaric oxygen (HBO) treatment consists of breathing $100 \%$ oxygen at $2-4$ times the normal atmospheric pressure, which results in saturated haemoglobin and increased oxygen in the circulation [5-7]. While HBO is applied during or briefly before the radiation treatment, multiple clinical studies, including multi-centre randomised trials by the medical research council (MRC) in late 1970s and mid-1980s, showed that HBO treatment improved local control in patients with head and neck squamous cell carcinoma (HNSCC) or cervical cancer, compared to normal air. However, technical challenges derived from the decompression of the hyperbaric chamber, due to the radiation equipment and severe tissue damage, limited the use of $\mathrm{HBO}$ in radiation treatment [8]. Thus, carbogen breathing ( $95 \%$ oxygen $+5 \%$ carbon dioxide) was suggested as an alternative to $\mathrm{HBO}$ as it could promote oxygen delivery due to vasodilation and increased blood flow induced by carbon dioxide $[9,10]$. Nonetheless, carbogen breathing showed mixed results, which could be attributed to inconsistencies in the amounts of time patients were subjected to carbogen breathing [11,12]. Although carbogen treatment was well-tolerated by paediatric patients with high-risk brain stem glioma, no efficacy was found when combined with radiation [9].

Nicotinamide is a vitamin B3-derived molecule and its initial radiosensitising effect was thought to be mediated by the inhibition of the DNA damage repair (DDR) pathway specifically by blocking poly(ADP-ribose) polymerase 1 (PARP1), which is responsible for nucleotide excision repair (BER) [10]. The combination of carbogen with nicotinamide seems to target both acute and chronic hypoxia. Further studies suggested that nicotinamide could reduce acute hypoxia by inhibiting intermittent vascular shut down [11,12]. Accelerated radiotherapy with carbogen and nicotinamide (ARCON) trials showed a better patient survival and outcome in bladder and laryngeal cancer [13-16]. Although ARCON 
trials indicated the effectiveness of carbogen breathing as an adjuvant treatment regimen, it is necessary to consider other studies questioning the use of carbon dioxide in patients and the effectiveness of carbogen or the combination of carbogen and nicotinamide when compared to $\mathrm{HBO}[17,18]$.

\section{Hyperthermia}

Hyperthermia (HT) is a treatment based on applying heat $\left(40\right.$ to $\left.45^{\circ} \mathrm{C}\right)$ to tissues to above physiological temperatures. HT can be directly applied to treat tumours, but due to the technical difficulties in achieving cytotoxic temperatures, it is mainly used as an adjuvant therapy in combination with radiation or chemotherapy [19-24]. HT promotes protein denaturation and increases membrane fluidity and cell cycle inhibition. In addition to its direct action against tumour cells, HT is reported to inhibit DDR and promote tumour oxygenation, which might be more clinically relevant as they are directly related to tumour radiosensitivity $[25,26]$.

Although HT has been used since ancient times to treat a variety of diseases. Its clinical use for cancer patients was introduced in the 1900s, which was accelerated by the development of the devices to heat tumours $[27,28]$. In patients, HT is externally or interstitially given using microwaves, radiofrequencies, electromagnetic radiation, or ultrasound. The accumulation of evidence supporting the beneficial effects from HT in cells, animals and patients eventually led to clinical trials in combination with radiation in the 1970s and 1980s. However, mixed patient outcomes put into question the efficacy of the combination of HT and radiation. Nevertheless, the analysis of five UK-led randomised trials of radiation and HT by Vernon et al., multi-centre trials by Overgaard et al., and studies by Jones et al. and van der Zee et al. suggested that the combination of HT and radiation was beneficial for some groups of patients, including locally recurrent breast cancer, cervical cancer, and melanoma [29-39]. Moreover, multiple studies further supported the beneficial effects of HT in paediatric and adolescent patients with a variety of tumour types, including malignant germ cell tumours, soft tissue sarcoma, and chondrosarcomas $[40,41]$.

The biggest clinical challenge when delivering HT is to achieve cytotoxic temperatures $\left(>43{ }^{\circ} \mathrm{C}\right.$ ) and to overcome thermotolerance [42,43]. It is hard to apply sufficient heat to induce cell death, without causing pain and damage to normal tissues. In addition, the isothermal (homogeneous) heating of tumour tissues is a major technical limitation in trying to reach the target temperature for the treatment. Non-homogeneous tissue heating also results in the differential heat resistance of tumour areas, which is caused by the formation of heat shock proteins (HSPs) [42]. Recent technical advances enabled real-time, MRI-guided thermotherapy (or MR thermometry) to define the heated region while monitoring the temperature rise [44,45]. The meta-analyses from breast cancer, cervical cancer, and HNSCC trials still support the advantage of HT with multimodal therapy [46-48]. Therefore, it is still necessary to fully understand the biological effects of HT and to set up a better strategy for the treatment schedule, patient groups, and the combination of other therapeutic modalities.

Multiple studies suggest that tumour oxygenation is caused by increased blood flow, perfusion, and decreased oxygen consumption, specifically at mild HT temperatures $\left(39-43^{\circ} \mathrm{C}\right)[30,49-53]$. While tumours are often characterised by immature vascularisation, mild HT increases tumour blood flow and perfusion in order to increase oxygen delivery. A study using a rat tumour model determined that at $40.5-41.5^{\circ} \mathrm{C}$ tumour oxygenation increased immediately and persisted even $24 \mathrm{~h}$ after treatment, which was correlated with changes in blood flow [54]. Interestingly, at $42.5^{\circ} \mathrm{C}$ the trends of tumour oxygenation were different from those of blood flow. Although there was a decrease in blood flow $24 \mathrm{~h}$ after HT, tumour oxygenation was significantly enhanced at this temperature. This observation was supported by another study in spontaneous canine soft-tissue sarcomas [55]. These studies suggested that HT-induced tumour oxygenation was regulated by additional biological factors other than blood flow and perfusion. The study by Vaupel et al. revealed lower oxygen consumption rates at temperatures higher than $42^{\circ} \mathrm{C}$ [56]. After $\mathrm{HT}$, dysregu- 
lated mitochondrial function and disrupted mitochondrial membrane potential were also observed [57-59]. In addition, the elevated lactate production in tumour cells or in mouse tissues after HT suggested that HT induced tumour glycolysis [24,60-63]. When combined, these studies indicate that HT alters cancer metabolism by inhibiting oxidative phosphorylation and promoting glycolysis, which results in a decreased oxygen consumption. The study by Moon et al. showed that mild HT lowered oxygen consumption, while the mitochondrial membrane potential was disrupted [60]. This study also indicated, using both in vitro and in vivo breast cancer models, that the high temperature-induced activation of HIF pathways at early time points (0-6 h after HT) was the main regulator of blood perfusion and metabolism. The radiosensitising effect of mild-HT-induced oxygenation was further observed in a fibrosarcoma model [61]. More interestingly, this study showed that having HT before radiation had a higher anti-tumour effect than having HT after radiation. This supports the idea that tumour oxygenation is required for radiosensitisation. While the previous clinical study by Jones et al. clearly supported the correlation between tumour oxygenation in mild HT temperatures and positive patient responses, recent clinical trials in advanced cervical cancer patients demonstrated that a short time interval between HT and radiation resulted in better patient outcomes [52,62]. This emphasises the importance of the treatment schedule.

The effect of HT in DDR is another aspect that can be exploited for radiosensitisation. HT was reported to induce increases in ATM and $\gamma \mathrm{H} 2 \mathrm{AX}$ pathways as well as p53 expression [23,63-65]. This induction in key pathways in DDR suggests a role in early DDR responses. The inhibition of non-homologous end joining (NHEJ) and homologous recombinant (HR) pathways by decreasing the expression of Ku80 and BRCA2 also suggests that HT might have a beneficial effect in combination with DDR-targeted therapy $[37,66]$. Currently, there is an ongoing clinical trial with the combination of HT and Olaparib in breast cancer patients with a chest wall recurrence (NCT03955640).

The modulation of the immune system by HT also suggests the potential of using HT as a systemic treatment. The increased augmentation of the major histocompatibility complex (MHC) class I, and the enhanced infiltration of NK cells, CD8+ T cells, and B cells were observed after HT [67-70]. These studies suggested that the combination of HT, radiation and immunotherapy may enhance treatment efficacy.

Taken together, mild HT has a strong potential as an adjuvant treatment to overcome tumour hypoxia. To obtain clearer insights into the relationship between HT treatment and tumour oxygenation at the molecular level, further investigation is required. Furthermore, the underlying mechanisms of heat resistance (heat shock proteins, HIF pathways, ROS, and endothelial-to-mesenchymal transition) need to be considered to identify therapeutic targets or to better stratify patient groups into benefitting from HT [60,71-74].

\section{Hypoxia-Activated Prodrugs}

In the 1980s, several studies proposed targeting hypoxia by developing hypoxiaspecific cytotoxins, which are now known as hypoxia-activated prodrugs (HAPs) [75,76]. HAPs are compounds that can be selectively reduced by endogenous cellular oxidoreductases to yield cytotoxic agents under hypoxic conditions. This bioreductive process is normally inhibited by molecular oxygen, which directly competes for the single electron of the initially reduced prodrug, preventing the complete reduction of the compound into its active form. The superoxide product is then detoxified by superoxide dismutase (SOD) resulting in a low toxicity in normal tissues. However, under hypoxia, the prodrug is reduced by completely yielding the active compound, thus allowing for the specific target of hypoxic regions [77].

Since the 1960s, the discovery of a direct relation between the electron affinity of the sensitising agent and the degree of radiosensitisation led to the study of nitroaromatic compounds as potential hypoxia modifiers [78]. These types of HAPs present high electron affinities, which allow them to fix or stabilise radiation-induced DNA damage making it unrepairable, and thus lethal [79]. The chemical properties of nitroaromatic 
drugs under hypoxia resemble those of oxygen, hence, they have often been referred as "oxygen mimetics".

The first nitroaromatic drugs, which were tested as radiosensitisers, were metronidazole and misonidazole. These nitroaromatic molecules showed a high effectiveness both in vitro and in preclinical models [80,81]. However, clinical trials failed for both compounds, showing no increases in patient survival between the combination treatment with radiation and radiation alone [82-84]. The failure of these trials was attributed to a high toxicity, which was caused by a high volume of distribution and a longer half-life of the drug in humans compared to murine models. As a result, the high toxicity of these compounds limited the maximal tolerable dose, which resulted in a low radiosensitisation. To increase the efficacy of the treatment, three new nitroaromatic compounds with improved pharmacokinetic properties and reduced toxicity were developed and tested clinically: etanidazole, pimonidazole, and nimorazole. Although etanidazole was involved in phase II and phase III clinical trials, it did not show any improvement for patients with neither HNSCC nor small-cell lung cancer (SCLC) [85,86]. Pimonidazole also failed to provide evidence of the benefit of a combination treatment with radiation, when compared to only radiation in cervical carcinoma patients [87]. However, currently, pimonidazole is widely used for measuring tumour hypoxia by immunohistochemical staining [88].

In contrast to etanidazole and pimonidazole, nimorazole showed promising clinical results. It improved the radiotherapeutic effect in supraglottic and pharynx tumours without side effects in a Danish head and neck cancer study (DAHANCA) [89]. As a result, nimorazole has now become a standard treatment for HNSCC in Denmark, although it is still necessary to assess whether nimorazole directly changes the oxygenation status of patient tumours. Recently, a phase I/II clinical trial for p16-negative HNSCC reported positive results for the combination of nimorazole and radiotherapy [90]. In addition to two ongoing clinical trials for nimorazole in Denmark (NCT02661152 and NCT02976051), there is a randomised clinical trial in the UK for patients with HNSCC undergoing radiotherapy who are not suitable for synchronous chemotherapy or cetuximab (NCT01950689).

\section{Tirapazamine}

Following the development of the initial set of oxygen-mimetic HAPs, new agents targeting both hypoxia and DNA were developed. Several compounds have been reported to reduce tumour hypoxia in vitro and were studied in the clinic, including mitomycin $C$, PR-104, evofosfamide (TH-302), A4QN, and tirapazamine (TPZ), as extensively reviewed elsewhere [91,92]. In this review, we specifically focus on TPZ as its usage to target tumour hypoxia has recently been revisited and is currently being clinically tested.

TPZ or 3-amino-1,2,4-benzotriazine1,4-dioxide is a HAP which can be reduced to its cytotoxic form by one electron reductases (i.e., NADPH-dependent cytochrome P450 reductase). This type of reduction leads to the formation of a TPZ radical and the release of hydroxide radical (OH·), then the TPZ radical is further reduced to TPZ 1-oxide by acquiring another electron $[93,94]$. TPZ can also be reduced by two electron reductases such as NAD(P)H dehydrogenase [quinone] 1 (NQO1) to TPZ 1-oxide directly [95]. The cytotoxicity of TPZ increases many fold under hypoxia. However, both forms of the reduced TPZ induce DNA damage through SSB and DSB, therefore TPZ can also be toxic under normoxia. The cytotoxic action of TPZ under normoxia is probably linked to the production of superoxides $\left(\mathrm{O}_{2}{ }^{-}\right)$and the activity of NQO1 [95]. NQO1 can reduce TPZ under normoxia, TPZ-1-oxide is then oxidized back to TPZ which produces $\mathrm{O}_{2}^{-} ; \mathrm{O}_{2}^{-}$ can then be converted into hydrogen peroxide or hydroxyl peroxide, which can damage normal tissues [96]. While the cytotoxic effect of TPZ is dependent on low oxygen tensions, tumour reperfusion (represented by tissue diffusion coefficients) and $\mathrm{K}$ values (the oxygen concentration is changed to halve the cytotoxic potency) also play a role in the prodrug activation and efficacy [97-99].

TPZ was found to have an additive cell killing effect with radiation and cisplatin tumour cell survival [100-102]. When given with cisplatin, which mainly targets normoxic 
tumour cells, TPZ increased therapeutic efficacy. Moreover, TPZ did not potentiate the cisplatin's toxicity to normal tissues, which made it a potential candidate for clinical trials [103]. Phase I clinical trials of HNSCC, cervical cancer, and limited-stage SCLC showed promising results with the combination treatment of TPZ with cisplatin and radiation, as well as etoposide in the case of SCLC, decreasing the hypoxic tumour areas in patients [104-107]. Some trials showed the limited efficacy of TPZ in solid tumours. However, the majority of Phase I clinical trials suggested that TPZ, in combination with chemotherapy and radiation, compared to TPZ alone, had the potential to provide better tumour control $[108,109]$. The dose escalation studies for the TPZ showed cytotoxicity ranging from muscle cramping, vomiting and nausea, febrile neutropenia, and reversible deafness [108-114].

Phase II trials of TPZ also showed effectiveness when combined with cisplatin, radiation, or gemcitabine in HNSCC, non-small cell lung cancer (NSCLC), advanced or recurrent cervical cancer, and metastatic melanoma [110-116]. Additionally, the limited stage SCLC trial where TPZ was tested with etoposide, cisplatin and radiation, resulted in a better overall survival [117]. In contrast, a Phase II trial using radiation with TPZ on glioblastoma multiform did not show any differences in survival, indicating that there might be a tumour-type dependent action of TPZ [118].

Phase III clinical trials of cervical carcinoma did not find that TPZ and cisplatin to improve overall survival or progression free survival compared to cisplatin alone in stage IB2, IIA, IIB, IIIB, and IVA patients [119]. The advanced HNSCC trials also resulted in non-statistically significant differences between the combination therapy of cisplatin, TPZ and radiation and the combination of cisplatin and radiation [120]. A Phase III trial of the combination of cisplatin and TPZ in subjects with advanced, previously untreated, non-small cell lung tumours (CATAPULT I) showed a higher survival for the combination of TPZ and cisplatin compared to cisplatin alone. In contrast, the CATAPULT II trial showed that the combination of TPZ and cisplatin was less effective than the combination of etoposide and cisplatin [121,122]. Additionally, the CATAPULT II trial showed that the TPZ group also had higher toxicity. The results of Phase III trials were underwhelming and showed no benefit in having TPZ included in the treatment of the aforementioned cancer types. Furthermore, some even showed a higher toxicity when TPZ was included. However, it needs to be noted that none of these trials fully determined whether TPZ treatment promoted tumour oxygenation, which questions whether the drug was delivered properly and whether it can target hypoxic tumour cells effectively.

Interestingly, in paediatric cancers (refractory solid tumours and rhabdomyosarcoma), TPZ did not further increase toxicity when combined with cyclophosphamide or cyclophosphamide/doxorubicin $[123,124]$. However, in these studies, TPZ treatment failed to improve patient outcomes.

Although TPZ did not progress past the clinical trials due to the limited success in Phase III, recent studies suggest that TPZ might still be efficacious. Second generation TPZ analogues might protect cardiomycites from doxorubicin-induced toxicity [125]. Recently, it was found, in inflammatory breast cancer cell lines, that TPZ in combination with PARP1 inhibitors, olaparib and talazoparib, was synergistic [126]. Therefore, combining PARP1 inhibitors with TPZ could represent a new approach for targeting solid hypoxic tumours. Since TPZ-induced DNA damage was found to be repaired by enzymes involved in BER, it could be a logical next step to use PARP inhibitors and TPZ in combination [127]. Moreover, considering that the PARP inhibitor is also used in combination with HT, trimodality therapy with PARPi, TPZ, and HT might further enhance the radiosensitising effect.

Another possible usage of HAPs is to help deliver other anticancer agents. For instance, 2-nitroimidazole prodrugs were used to deliver the PARP1 inhibitor, 5-bromoisoquinolon [128]. Using multicellular layers (MCLs), a type of cell culture that models the extravascular compartment of tumours [1], a new generation of TPZ analogues have been developed. These analogues, such as SN30000, have higher tissue diffusion coefficients based on physicochemical properties such as molecular weight, lipophilicity, and hydrogen bond 
donors and acceptors [129]. Similar to the case of 2-nitroimidazole, it could be possible to deliver anticancer drugs and release them under hypoxia using new generations of HAPs. This could minimize chemotherapy-related toxicity while maximizing the direct targeting of tumour cells.

TPZ was also found to be capable of suppressing osteosarcoma cells under hypoxia in part through SLC7A11-mediated ferroptosis, which is a recently discovered type of cell death [130]. Interestingly, ferroptosis has been highlighted as a possible sensitiser of radioresistant cells [131]. Therefore, TPZ could be paired with ferroptosis inducers such as radiation and the ferroptosis inducer sulfasalazine [132]. Recently, preclinical studies of TPZ in treating liver tumours in transgenic mice, by inducing hypoxia through arterial embolization, have shown increased levels of tumour suppression [133]. The combination of TPZ and transarterial embolisation for unresectable hepatocellular carcinoma (HCC) patients is currently in clinical trials (NCT03145558) after the promising outcomes of a Phase I clinical trial [134].

\section{Hypoxia-Inducible Factor (HIF) Inhibitors}

At the molecular level, hypoxia stabilises the hypoxia-inducible transcription factor (HIF), which regulates more than 100 genes involved in tumour angiogenesis, apoptosis, invasion, metastasis and metabolism [135,136]. HIF consists of $\alpha$ and $\beta$ subunits. Unlike the HIF- $\beta$ subunit, which is constitutively active, the expression of the HIF- $\alpha$ subunit is regulated by oxygen, iron, free radicals and growth factors. Under normoxic conditions, HIF- $\alpha$ is hydroxylated by prolyl-4-hydroxylase (PHD) and bound to the von Hippel Lindau protein (VHL) to undergo proteasomal degradation by forming the E3 ligase complex [137-139]. Hypoxia (but also free radicals or metabolic intermediates) inhibits PHD activity, and thus stabilises HIF- $\alpha$. When stabilised, HIF- $\alpha$ forms a heterodimer with $\beta$ and binds to the hypoxia response element (HRE) with cofactors CBP and p300 to transactivate the expression of many downstream genes [140].

HIF pathways are highly upregulated in most tumour types and their expression is correlated with poor patient outcomes [135,141-143]. The expression of HIF- $\alpha$ is also upregulated after radiation or chemotherapy, indicating that HIF pathways are significantly involved in treatment resistance [144-148]. Therefore, there is a strong rationale to target HIF pathways to sensitise hypoxic tumour cells to treatment.

Multiple attempts have been made to target HIF to inhibit hypoxia-driven cancer progression. However, only those indirectly acting on HIF are currently used in clinical trials, including camptothecin and bortezomib $[149,150]$. Other small molecules in clinical trials such as the Hsp90 inhibitor (17-AAG), digoxin, and 2-methoxyestradiol (2ME2) also act non-specifically on HIF through the inhibition of HIF synthesis or stabilisation [151-155]. On the contrary, PT2385 and its derivative, PT2399, specifically bind to the per-arnt-sim-B (PAS-B) domain of HIF2 and interfere in its heterodimersation with HIF- $\beta$ [156]. The efficacy of PT2399 was proven in a preclinical clear-cell renal cancer cell (ccRCC) model, which exhibited an enhanced HIF activation due to VHL mutation $[157,158]$. The recent outcome of a Phase I clinical trial showed both the safety and efficacy of PT2385 as a direct inhibitor of HIF-2 in ccRCC. In contrast, in vivo studies using a glioblastoma model showed no benefits in survival when comparing PT2385 treatment combined with radiation (RT)/temozolomide (TMZ) to RT/TMZ treatment [159]. Despite this, PT2977 (MK-6482), a more potent second-generation HIF-2 inhibitor, is currently in a Phase III clinical trial in advanced RCC (NCT04195750) [160-163]. It is important to note that the tumour oxygenation status was not evaluated in any of these studies, indicating that further investigation is required to determine whether this treatment is more beneficial to the specific patient population with a high HIF-2 expression or elevated tumour hypoxia. The ongoing Phase II clinical trial (NCT03216499) with glioblastoma patients will provide further information on whether PT2385 can be used to target HIF and hypoxia to enhance patient treatment outcome. 


\section{Targeting Metabolism}

An emerging alternative approach to alleviate tumour hypoxia in order to increase radiosensitivity is to reprogramme the cellular metabolism into lower oxygen consumption rates (OCR). Oxygen is mostly used by mitochondria through oxidative phosphorylation (OXPHOS) and the electron transport chain (ETC). Therefore, reducing cellular OCR by inhibiting OXPHOS in well-perfused and peri-hypoxic areas of tumours increases oxygen availability and facilitates the diffusion of the non-utilised oxygen into hypoxic areas, reducing tumour hypoxia and increasing radiation responses [164,165].

There are several advantages to reducing tumour hypoxia by lowering OCR in tumours. Computational analysis indicated that inhibiting oxygen consumption inadequately perfused tumour regions, with a decrease as little as $30 \%$, was more effective at reducing tumour hypoxia than increasing blood flow or elevating the oxygen concentration in blood [166]. Another key advantage is that reducing oxygen consumption does not require the diffusion of drugs into hypoxic and poorly vascularised areas, as OXPHOS inhibitors act on well-perfused areas allowing oxygen to infiltrate and oxygenate hypoxic areas. Additionally, this strategy can be broadly applied to different types of hypoxic tumours, as inhibiting OXPHOS reduces OCR in several types of cancer [164].

Various treatments that aim to target the ETC to impair OXPHOS and decrease oxygen consumption are currently being tested. One of these treatments is the commonly prescribed, anti-diabetic biguanide, metformin. Metformin was first highlighted as a potential cancer treatment after the observation that diabetic patients treated with metformin had a lower cancer incidence and better outcome than patients with or without diabetes taking other medications [167-170]. Two different mechanisms of lowering tumour growth were attributed to metformin: the reduction in insulin availability at the organismal level and the inhibition of complex I of the ETC [170]. Complex I inhibition decreases ATP production activating AMP-activated protein kinase (AMPK) and inhibiting the mechanistic target of the rapamycin complex 1 (mTORC1), hence, reducing the overall OCR [171,172]. In fact, metformin was shown to decrease OCR, tumour hypoxia and increase radiosensitisation in vitro, in spheroids and in xenografted tumours [173-177]. Moreover, there are two ongoing phase II clinical trials for metformin as a tumour oxygenating agent in locally advanced cervical cancer (LACC) (NCT04275713 and NCT02394652) and a proof-of-principle clinical trial for HNSCC (NCT03510390). Additionally, metformin is also currently being tested in a phase I clinical trial for paediatric relapsed or refractory solid tumours (NCT01528046).

One of the controversies around using metformin to reduce tumour hypoxia is that the OCR reduction reported was considerably low $(<20 \%)$. Hence, a more potent biguanide, phenformin, was proposed as an alternative. Phenformin was reported to decrease OCR levels and reduce radioresistance in a xenograft model of colorectal cancer [178]. Similarly, phenformin was shown to reduce tumour growth through the complex I inhibition in mouse models from a variety of cancer types [175,179-183]. A Phase I clinical trial is currently recruiting melanoma patients to test the efficacy of phenformin in combination with BRAF and MEK inhibitors (NCT03026517). Similarly, several new compounds are reported to target complex I with a high affinity and specificity, including BAY87-2243 [184], ME-344 [185] and IACS-010759 [186,187]. These complex I-inhibitors were introduced in phase I clinical trials. However, the clinical trial for BAY87-2243 was terminated due to toxicity (NCT01297530) and the trial for ME-344 resulted in no clinical efficacy [188]. IACS-010759 is currently under phase I clinical trials in solid tumours (NCT03291938) and relapsed/refractory acute myeloid leukaemia (AML) (NCT02882321). Interestingly, IACS-010759 was tested in combination with radiotherapy and anti-PD-1 in PD-1-resistant NSCLC, resulting in a prolonged survival time [189]. However, it is yet unclear whether the prolonged survival effect is directly related to the alleviation of tumour hypoxia.

Arsenic trioxide is a well-known inhibitor of the complex IV in the ETC; it is an FDA-approved treatment for acute promyelocytic leukaemia (APL) and is involved in numerous clinical trials in other cancer types. It was shown that arsenic trioxide reduced tumour hypoxia in Lewis lung carcinoma (LLC) and transplantable mouse liver (TLT) with 
a consequent increase in radiotherapy response [190]. Arsenic trioxide affects numerous intracellular signal transduction pathways and alters several cellular functions [191]. Therefore, it is still unclear whether this drug is capable of reducing OCR levels to alleviate tumour hypoxia at the concentration used in clinic.

Atovaquone is an FDA-approved anti-malarial agent that also showed OCR inhibition and its subsequent tumour hypoxia reduction in vitro and in vivo. This ubiquinone analogue acts as a complex III inhibitor reducing cellular oxygen consumption without inducing cell death. Atovaquone was reported to reduce the OCR by more than $80 \%$ in several types of cancer in vitro, as well as a significant tumour growth reduction in xenograft models [173]. The first proof-of-principle clinical trial with atovaquone as a tumour hypoxia treatment for NSCLC (NCT02628080) was finalised with highly promising results, indicating that atovaquone can reduce tumour hypoxia and exert antitumoral effects at the mRNA level [192]. Hypoxia imaging using PET-CT and dynamic contrast-enhanced (DCE) MRI clearly showed a reduced hypoxic tumour volume and increased perfusion in atovaquone-treated patients. Atovaquone is currently undergoing a Phase I clinical trial in combination with chemoradiation in NSCLC (NCT04648033). In addition, its possible use in paediatric cancer patients is suggested by a study showing the safety of atovaquone as a preventive treatment for Pneumocistis carinii pneumonia in children with leukaemia [193]. Other anti-parasitic drugs such as ivermectin, mefloquine, quinacrine, and proguanil were tested in vitro and in vivo as mitochondrial function inhibitors and showed a potential to decrease tumour hypoxia [194].

Overall, targeting OXPHOS to reduce tumour hypoxia and increase radiosensitivity represents a shift away from focusing on hypoxic regions and overcomes the need to supply drugs into diffusion-limited hypoxic areas. Although at an early stage, several ETC inhibitors have been developed and are being tested clinically with promising results and will hopefully lead to new therapies to alleviate tumour hypoxia.

\section{Conclusions}

For over a century, extensive efforts have been made to target tumour hypoxia in both experimental and clinical settings. It is critical to develop treatments that aim to reduce low oxygen environments within tumours and inhibit tumour progression and treatment resistance. To overcome hypoxia, multiple attempts were made to increase oxygen delivery, decreasetumour oxygen consumption, specifically target hypoxic cells, and inhibit HIF pathways. Although most of the trials did not accomplish a successful translation into the clinic, these studies still support the importance of hypoxia targeting to promote tumour control and patient survival. Technological advances and a better comprehension of tumour biology revived some of these historical treatments. Here, we reviewed several examples of these advances, such as the development of real time MRIguided thermotherapy (MR thermometry). MR thermometry allows for the monitoring and control of tumour tissue temperature during HT, hence improving the application of HT. We also reviewed several second-generation molecules with improved pharmacokinetics and a higher potency, such as nimorazole or the HIF-2 inhibitor, PT2977, which showed promising results. Furthermore, we discussed the alternative usage of treatments that failed in clinical trials but are now being tested in combination with other inhibitors, such as TPZ in combination with PARP1 inhibitors. Lastly, we highlighted examples of drugs that could be repurposed, such as the anti-diabetic metformin and the anti-malarial atovaquone. These compounds were shown to reduce tumour hypoxia and are currently being tested as radiosensitisers. Therefore, we hope that combining efforts to find old and new remedies to target hypoxia will soon translate into more effective therapeutic regimens.

Author Contributions: Conceptualization, E.J.M.; writing—original draft preparation, E.J.M., N.V.-L., M.B.; writing-review and editing, E.J.M., N.V.-L., M.B.; supervision, E.J.M.; funding acquisition, E.J.M. All authors have read and agreed to the published version of the manuscript.

Funding: This research was funded by MRC QQR programme grant, grant number MC_UU_00001/11. 
Institutional Review Board Statement: Not applicable.

Informed Consent Statement: Not applicable.

Data Availability Statement: Not applicable.

Conflicts of Interest: The authors declare no conflict of interest.

\section{References}

1. Wilson, W.R.; Hay, M.P. Targeting hypoxia in cancer therapy. Nat. Rev. Cancer 2011, 11, 393-410. [CrossRef]

2. Bristow, R.G.; Hill, R.P. Hypoxia and metabolism. Hypoxia, DNA repair and genetic instability. Nat. Rev. Cancer 2008, 8, 180-192. [CrossRef]

3. Hall, E.J.; Giaccia, A.J. Radiobiology for the Radiologist, 6th ed.; Lippincott Williams \& Wilkins: Philadelphia, PA, USA, 2006.

4. Comerford, K.M.; Wallace, T.J.; Karhausen, J.; Louis, N.A.; Montalto, M.C.; Colgan, S.P. Hypoxia-inducible factor-1-dependent regulation of the multidrug resistance (MDR1) gene. Cancer Res. 2002, 62, 3387-3394.

5. Horsman, M.R.; Overgaard, J. The impact of hypoxia and its modification of the outcome of radiotherapy. J. Radiat. Res. 2016, 57 (Suppl. 1), i90-i98. [CrossRef] [PubMed]

6. Horsman, M.R.; Sorensen, B.S.; Busk, M.; Siemann, D.W. Therapeutic Modification of Hypoxia. Clin. Oncol. 2021. [CrossRef] [PubMed]

7. Rockwell, S.; Dobrucki, I.T.; Kim, E.Y.; Marrison, S.T.; Vu, V.T. Hypoxia and radiation therapy: Past history, ongoing research, and future promise. Curr. Mol. Med. 2009, 9, 442-458. [CrossRef]

8. Bennett, M.H.; Feldmeier, J.; Smee, R.; Milross, C. Hyperbaric oxygenation for tumour sensitisation to radiotherapy. Cochrane Database Syst. Rev. 2018, 4, CD005007. [CrossRef]

9. Chaplin, D.J.; Horsman, M.R.; Siemann, D.W. Further evaluation of nicotinamide and carbogen as a strategy to reoxygenate hypoxic cells in vivo: Importance of nicotinamide dose and pre-irradiation breathing time. Br. J. Cancer 1993, 68, 269-273. [CrossRef]

10. Siemann, D.W.; Hill, R.P.; Bush, R.S. The importance of the pre-irradiation breathing times of oxygen and carbogen $\left(5 \% \mathrm{CO}_{2}: 95 \%\right.$ $\mathrm{O}_{2}$ ) on the in vivo radiation response of a murine sarcoma. Int. J. Radiat. Oncol. Biol. Phys. 1977, 2, 903-911. [CrossRef]

11. Aquino-Parsons, C.; Hukin, J.; Green, A. Concurrent carbogen and radiation therapy in children with high-risk brainstem gliomas. Pediatr. Blood Cancer 2008, 50, 397-399. [CrossRef] [PubMed]

12. Surjana, D.; Halliday, G.M.; Damian, D.L. Role of nicotinamide in DNA damage, mutagenesis, and DNA repair. J. Nucleic Acids 2010, 2010, 157591. [CrossRef]

13. van Laarhoven, H.W.; Bussink, J.; Lok, J.; Punt, C.J.; Heerschap, A.; van Der Kogel, A.J. Effects of nicotinamide and carbogen in different murine colon carcinomas: Immunohistochemical analysis of vascular architecture and microenvironmental parameters. Int. J. Radiat. Oncol. Biol. Phys. 2004, 60, 310-321. [CrossRef] [PubMed]

14. Kaanders, J.H.; Bussink, J.; van der Kogel, A.J. ARCON: A novel biology-based approach in radiotherapy. Lancet Oncol. 2002, 3 , 728-737. [CrossRef]

15. Janssens, G.O.; Rademakers, S.E.; Terhaard, C.H.; Doornaert, P.A.; Bijl, H.P.; van den Ende, P.; Chin, A.; Marres, H.A.; de Bree, R.; van der Kogel, A.J.; et al. Accelerated radiotherapy with carbogen and nicotinamide for laryngeal cancer: Results of a phase III randomized trial. J. Clin. Oncol. 2012, 30, 1777-1783. [CrossRef] [PubMed]

16. Hoskin, P.; Rojas, A.; Saunders, M. Accelerated radiotherapy, carbogen, and nicotinamide (ARCON) in the treatment of advanced bladder cancer: Mature results of a Phase II nonrandomized study. Int. J. Radiat. Oncol. Biol. Phys. 2009, 73, 1425-1431. [CrossRef] [PubMed]

17. Janssens, G.O.; Rademakers, S.E.; Terhaard, C.H.; Doornaert, P.A.; Bijl, H.P.; van den Ende, P.; Chin, A.; Takes, R.P.; de Bree, R.; Hoogsteen, I.J.; et al. Improved recurrence-free survival with ARCON for anemic patients with laryngeal cancer. Clin. Cancer Res. 2014, 20, 1345-1354. [CrossRef]

18. Kaanders, J.H.; Pop, L.A.; Marres, H.A.; Bruaset, I.; van den Hoogen, F.J.; Merkx, M.A.; van der Kogel, A.J. ARCON: Experience in 215 patients with advanced head-and-neck cancer. Int. J. Radiat. Oncol. Biol. Phys. 2002, 52, 769-778. [CrossRef]

19. Brizel, D.M.; Hage, W.D.; Dodge, R.K.; Munley, M.T.; Piantadosi, C.A.; Dewhirst, M.W. Hyperbaric oxygen improves tumor radiation response significantly more than carbogen/nicotinamide. Radiat. Res. 1997, 147, 715-720. [CrossRef] [PubMed]

20. Brizel, D.M.; Lin, S.; Johnson, J.L.; Brooks, J.; Dewhirst, M.W.; Piantadosi, C.A. The mechanisms by which hyperbaric oxygen and carbogen improve tumour oxygenation. Br. J. Cancer 1995, 72, 1120-1124. [CrossRef]

21. Dewhirst, M.W.; Vujaskovic, Z.; Jones, E.; Thrall, D. Re-setting the biologic rationale for thermal therapy. Int. J. Hyperth. 2005, 21, 779-790. [CrossRef]

22. Elming, P.B.; Sorensen, B.S.; Oei, A.L.; Franken, N.A.P.; Crezee, J.; Overgaard, J.; Horsman, M.R. Hyperthermia: The Optimal Treatment to Overcome Radiation Resistant Hypoxia. Cancers 2019, 11, 60. [CrossRef] [PubMed]

23. Dewhirst, M.W.; Viglianti, B.L.; Lora-Michiels, M.; Hanson, M.; Hoopes, P.J. Basic principles of thermal dosimetry and thermal thresholds for tissue damage from hyperthermia. Int. J. Hyperth. 2003, 19, 267-294. [CrossRef]

24. Streffer, C. Metabolic changes during and after hyperthermia. Int. J. Hyperth. 1985, 1, 305-319. [CrossRef]

25. Oei, A.L.; Vriend, L.E.; Crezee, J.; Franken, N.A.; Krawczyk, P.M. Effects of hyperthermia on DNA repair pathways: One treatment to inhibit them all. Radiat. Oncol. 2015, 10, 165. [CrossRef] 
26. Lepock, J.R. Role of nuclear protein denaturation and aggregation in thermal radiosensitization. Int. J. Hyperth. 2004, 20, 115-130. [CrossRef]

27. Kampinga, H.H.; Dikomey, E. Hyperthermic radiosensitization: Mode of action and clinical relevance. Int. J. Radiat. Biol. 2001, 77, 399-408. [CrossRef]

28. Oleson, J.R. Eugene Robertson Special Lecture. Hyperthermia from the clinic to the laboratory: A hypothesis. Int. J. Hyperth. 1995, 11, 315-322. [CrossRef]

29. Lee, S.Y.; Fiorentini, G.; Szasz, A.M.; Szigeti, G.; Szasz, A.; Minnaar, C.A. Quo Vadis Oncological Hyperthermia (2020)? Front. Oncol. 2020, 10, 1690. [CrossRef]

30. Roussakow, S. The History of Hyperthermia Rise and Decline. Conf. Pap. Med. 2013, 213, 1-40. [CrossRef]

31. Emami, B.; Myerson, R.J.; Cardenes, H.; Paris, K.G.; Perez, C.A.; Straube, W.; Leybovich, L.; Mildenberger, M.; Kuske, R.R.; Devineni, V.R.; et al. Combined hyperthermia and irradiation in the treatment of superficial tumors: Results of a prospective randomized trial of hyperthermia fractionation (1/wk vs. 2/wk). Int. J. Radiat. Oncol. Biol. Phys. 1992, 24, 145-152. [CrossRef]

32. Jones, E.L.; Oleson, J.R.; Prosnitz, L.R.; Samulski, T.V.; Vujaskovic, Z.; Yu, D.; Sanders, L.L.; Dewhirst, M.W. Randomized trial of hyperthermia and radiation for superficial tumors. J. Clin. Oncol. 2005, 23, 3079-3085. [CrossRef]

33. Kapp, D.S.; Petersen, I.A.; Cox, R.S.; Hahn, G.M.; Fessenden, P.; Prionas, S.D.; Lee, E.R.; Meyer, J.L.; Samulski, T.V.; Bagshaw, M.A. Two or six hyperthermia treatments as an adjunct to radiation therapy yield similar tumor responses: Results of a randomized trial. Int. J. Radiat. Oncol. Biol. Phys. 1990, 19, 1481-1495. [CrossRef]

34. Myerson, R.J.; Scott, C.B.; Emami, B.; Sapozink, M.D.; Samulski, T.V. A phase I/II study to evaluate radiation therapy and hyperthermia for deep-seated tumours: A report of RTOG 89-08. Int. J. Hyperth. 1996, 12, 449-459. [CrossRef] [PubMed]

35. Overgaard, J.; Gonzalez Gonzalez, D.; Hulshof, M.C.; Arcangeli, G.; Dahl, O.; Mella, O.; Bentzen, S.M. Hyperthermia as an adjuvant to radiation therapy of recurrent or metastatic malignant melanoma. A multicentre randomized trial by the European Society for Hyperthermic Oncology. Int. J. Hyperth. 1996, 12, 3-20. [CrossRef] [PubMed]

36. Perez, C.A.; Pajak, T.; Emami, B.; Hornback, N.B.; Tupchong, L.; Rubin, P. Randomized phase III study comparing irradiation and hyperthermia with irradiation alone in superficial measurable tumors. Final report by the Radiation Therapy Oncology Group. Am. J. Clin. Oncol. 1991, 14, 133-141. [CrossRef]

37. Valdagni, R.; Amichetti, M. Report of long-term follow-up in a randomized trial comparing radiation therapy and radiation therapy plus hyperthermia to metastatic lymph nodes in stage IV head and neck patients. Int. J. Radiat. Oncol. Biol. Phys. 1994, 28, 163-169. [CrossRef]

38. Valdagni, R.; Italia, C.; Montanaro, P.; Lanceni, A.; Lattuada, P.; Magnani, T.; Fiorino, C.; Nahum, A. Is the alpha-beta ratio of prostate cancer really low? A prospective, non-randomized trial comparing standard and hyperfractionated conformal radiation therapy. Radiother. Oncol. 2005, 75, 74-82. [CrossRef]

39. van der Zee, J.; Gonzalez Gonzalez, D.; van Rhoon, G.C.; van Dijk, J.D.; van Putten, W.L.; Hart, A.A. Comparison of radiotherapy alone with radiotherapy plus hyperthermia in locally advanced pelvic tumours: A prospective, randomised, multicentre trial. Dutch Deep Hyperthermia Group. Lancet 2000, 355, 1119-1125. [CrossRef]

40. Franckena, M.; Stalpers, L.J.; Koper, P.C.; Wiggenraad, R.G.; Hoogenraad, W.J.; van Dijk, J.D.; Warlam-Rodenhuis, C.C.; Jobsen, J.J.; van Rhoon, G.C.; van der Zee, J. Long-term improvement in treatment outcome after radiotherapy and hyperthermia in locoregionally advanced cervix cancer: An update of the Dutch Deep Hyperthermia Trial. Int. J. Radiat. Oncol. Biol. Phys. 2008, 70, 1176-1182. [CrossRef]

41. Vernon, C.C.; Hand, J.W.; Field, S.B.; Machin, D.; Whaley, J.B.; van der Zee, J.; van Putten, W.L.; van Rhoon, G.C.; van Dijk, J.D.; Gonzalez Gonzalez, D.; et al. Radiotherapy with or without hyperthermia in the treatment of superficial localized breast cancer: Results from five randomized controlled trials. International Collaborative Hyperthermia Group. Int. J. Radiat. Oncol. Biol. Phys. 1996, 35, 731-744. [CrossRef]

42. Seifert, G.; Budach, V.; Keilholz, U.; Wust, P.; Eggert, A.; Ghadjar, P. Regional hyperthermia combined with chemotherapy in paediatric, adolescent and young adult patients: Current and future perspectives. Radiat. Oncol. 2016, 11, 65. [CrossRef]

43. Tydings, C.; Sharma, K.V.; Kim, A.; Yarmolenko, P.S. Emerging hyperthermia applications for pediatric oncology. Adv. Drug Deliv. Rev. 2020, 163-164, 157-167. [CrossRef] [PubMed]

44. Li, G.C.; Mivechi, N.F.; Weitzel, G. Heat shock proteins, thermotolerance, and their relevance to clinical hyperthermia. Int. J. Hyperth. 1995, 11, 459-488. [CrossRef] [PubMed]

45. Overgaard, J.; Nielsen, O.S. The importance of thermotolerance for the clinical treatment with hyperthermia. Radiother. Oncol. 1983, 1, 167-178. [CrossRef]

46. Ozhinsky, E.; Salgaonkar, V.A.; Diederich, C.J.; Rieke, V. MR thermometry-guided ultrasound hyperthermia of user-defined regions using the ExAblate prostate ablation array. J. Ther. Ultrasound 2018, 6, 7. [CrossRef]

47. Stakhursky, V.L.; Arabe, O.; Cheng, K.S.; Macfall, J.; Maccarini, P.; Craciunescu, O.; Dewhirst, M.; Stauffer, P.; Das, S.K. Real-time MRI-guided hyperthermia treatment using a fast adaptive algorithm. Phys. Med. Biol. 2009, 54, 2131-2145. [CrossRef]

48. Datta, N.R.; Puric, E.; Klingbiel, D.; Gomez, S.; Bodis, S. Hyperthermia and Radiation Therapy in Locoregional Recurrent Breast Cancers: A Systematic Review and Meta-analysis. Int. J. Radiat. Oncol. Biol. Phys. 2016, 94, 1073-1087. [CrossRef]

49. Datta, N.R.; Rogers, S.; Klingbiel, D.; Gomez, S.; Puric, E.; Bodis, S. Hyperthermia and radiotherapy with or without chemotherapy in locally advanced cervical cancer: A systematic review with conventional and network meta-analyses. Int. J. Hyperth. 2016, 32, 809-821. [CrossRef] [PubMed] 
50. Datta, N.R.; Rogers, S.; Ordonez, S.G.; Puric, E.; Bodis, S. Hyperthermia and radiotherapy in the management of head and neck cancers: A systematic review and meta-analysis. Int. J. Hyperth. 2016, 32, 31-40. [CrossRef] [PubMed]

51. Song, C.W.; Park, H.; Griffin, R.J. Improvement of tumor oxygenation by mild hyperthermia. Radiat. Res. 2001, 155, 515-528. [CrossRef]

52. Brizel, D.M.; Scully, S.P.; Harrelson, J.M.; Layfield, L.J.; Dodge, R.K.; Charles, H.C.; Samulski, T.V.; Prosnitz, L.R.; Dewhirst, M.W. Radiation therapy and hyperthermia improve the oxygenation of human soft tissue sarcomas. Cancer Res. 1996, 56, 5347-5350. [PubMed]

53. Vujaskovic, Z.; Rosen, E.L.; Blackwell, K.L.; Jones, E.L.; Brizel, D.M.; Prosnitz, L.R.; Samulski, T.V.; Dewhirst, M.W. Ultrasound guided pO2 measurement of breast cancer reoxygenation after neoadjuvant chemotherapy and hyperthermia treatment. Int. J. Hyperth. 2003, 19, 498-506. [CrossRef]

54. Jones, E.L.; Prosnitz, L.R.; Dewhirst, M.W.; Marcom, P.K.; Hardenbergh, P.H.; Marks, L.B.; Brizel, D.M.; Vujaskovic, Z. Thermochemoradiotherapy improves oxygenation in locally advanced breast cancer. Clin. Cancer Res. 2004, 10, 4287-4293. [CrossRef]

55. Vujaskovic, Z.; Song, C.W. Physiological mechanisms underlying heat-induced radiosensitization. Int. J. Hyperth. 2004, 20, 163-174. [CrossRef] [PubMed]

56. Shakil, A.; Osborn, J.L.; Song, C.W. Changes in oxygenation status and blood flow in a rat tumor model by mild temperature hyperthermia. Int. J. Radiat. Oncol. Biol. Phys. 1999, 43, 859-865. [CrossRef]

57. Vujaskovic, Z.; Poulson, J.M.; Gaskin, A.A.; Thrall, D.E.; Page, R.L.; Charles, H.C.; MacFall, J.R.; Brizel, D.M.; Meyer, R.E.; Prescott, D.M.; et al. Temperature-dependent changes in physiologic parameters of spontaneous canine soft tissue sarcomas after combined radiotherapy and hyperthermia treatment. Int. J. Radiat. Oncol. Biol. Phys. 2000, 46, 179-185. [CrossRef]

58. Vaupel, P.W.; Kelleher, D.K. Pathophysiological and vascular characteristics of tumours and their importance for hyperthermia: Heterogeneity is the key issue. Int. J. Hyperth. 2010, 26, 211-223. [CrossRef]

59. Lepock, J.R.; Cheng, K.H.; Al-Qysi, H.; Sim, I.; Koch, C.J.; Kruuv, J. Hyperthermia-induced inhibition of respiration and mitochondrial protein denaturation in CHL cells. Int. J. Hyperth. 1987, 3, 123-132. [CrossRef] [PubMed]

60. Willis, W.T.; Jackman, M.R.; Bizeau, M.E.; Pagliassotti, M.J.; Hazel, J.R. Hyperthermia impairs liver mitochondrial function in vitro. Am. J. Physiol. Regul. Integr. Comp. Physiol. 2000, 278, R1240-R1246. [CrossRef] [PubMed]

61. Dressler, C.; Beuthan, J.; Mueller, G.; Zabarylo, U.; Minet, O. Fluorescence imaging of heat-stress induced mitochondrial long-term depolarization in breast cancer cells. J. Fluoresc. 2006, 16, 689-695. [CrossRef]

62. Tamulevicius, P.; Streffer, C. Bioluminescence imaging of metabolites in a human tumour xenograft after treatment with hyperthermia and/or the radiosensitizer pimonidazole. Int. J. Hyperth. 1997, 13, 235-245. [CrossRef]

63. Kelleher, D.K.; Engel, T.; Vaupel, P.W. Changes in microregional perfusion, oxygenation, ATP and lactate distribution in subcutaneous rat tumours upon water-filtered IR-A hyperthermia. Int. J. Hyperth. 1995, 11, 241-255. [CrossRef] [PubMed]

64. Moon, E.J.; Sonveaux, P.; Porporato, P.E.; Danhier, P.; Gallez, B.; Batinic-Haberle, I.; Nien, Y.C.; Schroeder, T.; Dewhirst, M.W. NADPH oxidase-mediated reactive oxygen species production activates hypoxia-inducible factor-1 (HIF-1) via the ERK pathway after hyperthermia treatment. Proc. Natl. Acad. Sci. USA 2010, 107, 20477-20482. [CrossRef]

65. Kim, M.; Kim, K.E.; Jeong, S.W.; Hwang, S.W.; Jo, H.; Lee, J.; Cho, D.; Park, H.J. Effects of the Ultra-High-Frequency Electrical Field Radiofrequency Device on Mouse Skin: A Histologic and Molecular Study. Plast. Reconstr. Surg. 2016, 138, 248e-255e. [CrossRef]

66. van Leeuwen, C.M.; Oei, A.L.; Chin, K.; Crezee, J.; Bel, A.; Westermann, A.M.; Buist, M.R.; Franken, N.A.P.; Stalpers, L.J.A.; Kok, H.P. A short time interval between radiotherapy and hyperthermia reduces in-field recurrence and mortality in women with advanced cervical cancer. Radiat. Oncol. 2017, 12, 75. [CrossRef] [PubMed]

67. Oei, A.L.; van Leeuwen, C.M.; ten Cate, R.; Rodermond, H.M.; Buist, M.R.; Stalpers, L.J.; Crezee, J.; Kok, H.P.; Medema, J.P.; Franken, N.A. Hyperthermia Selectively Targets Human Papillomavirus in Cervical Tumors via p53-Dependent Apoptosis. Cancer Res. 2015, 75, 5120-5129. [CrossRef]

68. Guan, J.; Stavridi, E.; Leeper, D.B.; Iliakis, G. Effects of hyperthermia on p53 protein expression and activity. J. Cell. Physiol. 2002, 190, 365-374. [CrossRef]

69. Hunt, C.R.; Pandita, R.K.; Laszlo, A.; Higashikubo, R.; Agarwal, M.; Kitamura, T.; Gupta, A.; Rief, N.; Horikoshi, N.; Baskaran, R.; et al. Hyperthermia activates a subset of ataxia-telangiectasia mutated effectors independent of DNA strand breaks and heat shock protein 70 status. Cancer Res. 2007, 67, 3010-3017. [CrossRef]

70. Burgman, P.; Ouyang, H.; Peterson, S.; Chen, D.J.; Li, G.C. Heat inactivation of Ku autoantigen: Possible role in hyperthermic radiosensitization. Cancer Res. 1997, 57, 2847-2850.

71. Ito, A.; Shinkai, M.; Honda, H.; Wakabayashi, T.; Yoshida, J.; Kobayashi, T. Augmentation of MHC class I antigen presentation via heat shock protein expression by hyperthermia. Cancer Immunol. Immunother. 2001, 50, 515-522. [CrossRef]

72. Burd, R.; Dziedzic, T.S.; Xu, Y.; Caligiuri, M.A.; Subjeck, J.R.; Repasky, E.A. Tumor cell apoptosis, lymphocyte recruitment and tumor vascular changes are induced by low temperature, long duration (fever-like) whole body hyperthermia. J. Cell. Physiol. 1998, 177, 137-147. [CrossRef]

73. Mace, T.A.; Zhong, L.; Kokolus, K.M.; Repasky, E.A. Effector CD8+ T cell IFN-gamma production and cytotoxicity are enhanced by mild hyperthermia. Int. J. Hyperth. 2012, 28, 9-18. [CrossRef] [PubMed]

74. Wan Mohd Zawawi, W.F.A.; Hibma, M.H.; Salim, M.I.; Jemon, K. Hyperthermia by near infrared radiation induced immune cells activation and infiltration in breast tumor. Sci. Rep. 2021, 11, 10278. [CrossRef] 
75. Corry, P.M.; Dewhirst, M.W. Thermal medicine, heat shock proteins and cancer. Int. J. Hyperth. 2005, 21, 675-677. [CrossRef]

76. Park, C.H.; Lee, M.J.; Ahn, J.; Kim, S.; Kim, H.H.; Kim, K.H.; Eun, H.C.; Chung, J.H. Heat shock-induced matrix metalloproteinase (MMP)-1 and MMP-3 are mediated through ERK and JNK activation and via an autocrine interleukin-6 loop. J. Investig. Dermatol. 2004, 123, 1012-1019. [CrossRef] [PubMed]

77. Ware, J.L.; Paulson, D.F.; Mickey, G.H.; Webb, K.S. Spontaneous metastasis of cells of the human prostate carcinoma cell line PC-3 in athymic nude mice. J. Urol. 1982, 128, 1064-1067. [CrossRef]

78. Lee, T.H.; Bu, J.; Kim, B.H.; Poellmann, M.J.; Hong, S.; Hyun, S.H. Sub-lethal hyperthermia promotes epithelial-to-mesenchymallike transition of breast cancer cells: Implication of the synergy between hyperthermia and chemotherapy. RSC Adv. 2019, 9, 52-57. [CrossRef]

79. Brown, J.M.; Koong, A. Therapeutic advantage of hypoxic cells in tumors: A theoretical study. J. Natl. Cancer Inst. 1991, 83, 178-185. [CrossRef]

80. Kennedy, K.A. Hypoxic cells as specific drug targets for chemotherapy. Anticancer Drug Des. 1987, 2, 181-194. [PubMed]

81. Guise, C.P.; Mowday, A.M.; Ashoorzadeh, A.; Yuan, R.; Lin, W.H.; Wu, D.H.; Smaill, J.B.; Patterson, A.V.; Ding, K. Bioreductive prodrugs as cancer therapeutics: Targeting tumor hypoxia. Chin. J. Cancer 2014, 33, 80-86. [CrossRef] [PubMed]

82. Adams, G.E.; Cooke, M.S. Electron-affinic sensitization. I. A structural basis for chemical radiosensitizers in bacteria. Int. J. Radiat. Biol. Relat. Stud. Phys. Chem. Med. 1969, 15, 457-471. [CrossRef]

83. Oronsky, B.T.; Knox, S.J.; Scicinski, J. Six degrees of separation: The oxygen effect in the development of radiosensitizers. Transl. Oncol. 2011, 4, 189-198. [CrossRef]

84. Kappen, L.S.; Lee, T.R.; Yang, C.C.; Goldberg, I.H.J.B. Oxygen transfer from the nitro group of a nitroaromatic radiosensitizer to a DNA sugar damage product. Biochemistry 1989, 28, 4540-4542. [CrossRef]

85. Asquith, J.C.; Foster, J.L.; Willson, R.L.; Ings, R.; McFadzean, J.A. Metronidazole (“Flagyl”). A radiosensitizer of hypoxic cells. Br. J. Radiol. 1974, 47, 474-481. [CrossRef]

86. Dische, S.; Saunders, M.; Lee, M.E.; Adams, G.; Flockhart, I.J.B.j.o.c. Clinical testing of the radiosensitizer Ro 07-0582: Experience with multiple doses. Br. J. Cancer 1977, 35, 567-579. [CrossRef] [PubMed]

87. Urtasun, R.; Feldstein, M.; Partington, J.; Tanasichuk, H.; Miller, J.; Russell, D.; Agboola, O.; Mielke, B.J.B.j.o.c. Radiation and nitroimidazoles in supratentorial high grade gliomas: A second clinical trial. Br. J. Cancer 1982, 46, 101-108. [CrossRef]

88. Dische, S.J.R. Chemical sensitizers for hypoxic cells: A decade of experience in clinical radiotherapy. Radiother. Oncol. 1985, 3, 97-115. [CrossRef]

89. Eschwège, F.; Sancho-Garnier, H.; Chassagne, D.; Brisgand, D.; Guerra, M.; Philippe Malaise, E.; Bey, P.; Busutti, L.; Cionini, L.; N'Guyen, T.; et al. Results of a european randomized trial of Etanidazole combined with radiotherapy in head and neck carcinomas. Int. J. Radiat. Oncol. 1997, 39, 275-281. [CrossRef]

90. Urtasun, R.C.; Palmer, M.; Kinney, B.; Belch, A.; Hewitt, J.; Hanson, J. Intervention with the hypoxic tumor cell sensitizer etanidazole in the combined modality treatment of limited stage small-cell lung cancer. A one-institution study. Int. J. Radiat. Oncol. Biol. Phys. 1998, 40, 337-342. [CrossRef]

91. Dische, S.; Chassagne, D.; Hope-Stone, H.F.; Dawes, P.J.D.K.; Roberts, J.T.; Yosef, H.; Bey, P.; Horiot, J.C.; Jacobson, A.; Frankendal, B.; et al. A trial of Ro 03-8799 (pimonidazole) in carcinoma of the uterine cervix: An interim report from the Medical Research Council Working Party on advanced carcinoma of the cervix. Radiother. Oncol. 1993, 26, 93-103. [CrossRef]

92. Krohn, K.A.; Link, J.M.; Mason, R.P. Molecular imaging of hypoxia. J. Nucl. Med. 2008, 49 (Suppl. 2), 129s-148s. [CrossRef]

93. Overgaard, J.; Sand Hansen, H.; Overgaard, M.; Bastholt, L.; Berthelsen, A.; Specht, L.; Lindeløv, B.; Jørgensen, K. A randomized double-blind phase III study of nimorazole as a hypoxic radiosensitizer of primary radiotherapy in supraglottic larynx and pharynx carcinoma. Results of the Danish Head and Neck Cancer Study (DAHANCA) Protocol 5-85. Radiother. Oncol. 1998, 46, 135-146. [CrossRef]

94. Saksø, M.; Jensen, K.; Andersen, M.; Hansen, C.R.; Eriksen, J.G.; Overgaard, J. DAHANCA 28: A phase I/II feasibility study of hyperfractionated, accelerated radiotherapy with concomitant cisplatin and nimorazole (HART-CN) for patients with locally advanced, HPV/p16-negative squamous cell carcinoma of the oropharynx, hypopharynx, larynx and oral cavity. Radiother. Oncol. 2020, 148, 65-72. [CrossRef] [PubMed]

95. Mistry, I.N.; Thomas, M.; Calder, E.D.D.; Conway, S.J.; Hammond, E.M. Clinical Advances of Hypoxia-Activated Prodrugs in Combination With Radiation Therapy. Int. J. Radiat. Oncol. 2017, 98, 1183-1196. [CrossRef]

96. Jackson, R.K.; Liew, L.P.; Hay, M.P. Overcoming Radioresistance: Small Molecule Radiosensitisers and Hypoxia-activated Prodrugs. Clin. Oncol. 2019, 31, 290-302. [CrossRef] [PubMed]

97. Wang, J.; Biedermann, K.A.; Wolf, C.R.; Brown, J.M. Metabolism of the bioreductive cytotoxin SR 4233 by tumour cells: Enzymatic studies. Br. J. Cancer 1993, 67, 321-325. [CrossRef]

98. Daniels, J.S.; Gates, K.S.; Tronche, C.; Greenberg, M.M. Direct evidence for bimodal DNA damage induced by tirapazamine. Chem. Res. Toxicol. 1998, 11, 1254-1257. [CrossRef]

99. Baker, M.A.; Zeman, E.M.; Hirst, V.K.; Brown, J.M. Metabolism of SR 4233 by Chinese hamster ovary cells: Basis of selective hypoxic cytotoxicity. Cancer Res. 1988, 48, 5947-5952.

100. Moriwaki, T.; Okamoto, S.; Sasanuma, H.; Nagasawa, H.; Takeda, S.; Masunaga, S.I.; Tano, K. Cytotoxicity of Tirapazamine (3-Amino-1,2,4-benzotriazine-1,4-dioxide)-Induced DNA Damage in Chicken DT40 Cells. Chem. Res. Toxicol. 2017, 30, 699-704. [CrossRef] 
101. Lartigau, E.; Guichard, M. Does tirapazamine (SR-4233) have any cytotoxic or sensitizing effect on three human tumour cell lines at clinically relevant partial oxygen pressure? Int. J. Radiat. Biol. 1995, 67, 211-216. [CrossRef]

102. Zeman, E.M.; Brown, J.M.; Lemmon, M.J.; Hirst, V.K.; Lee, W.W. SR-4233: A new bioreductive agent with high selective toxicity for hypoxic mammalian cells. Int. J. Radiat. Oncol. Biol. Phys. 1986, 12, 1239-1242. [CrossRef]

103. Marcu, L.; Olver, I. Tirapazamine: From bench to clinical trials. Curr. Clin. Pharmacol. 2006, 1, 71-79. [CrossRef]

104. Masunaga, S.; Ono, K.; Hori, H.; Shibata, T.; Suzuki, M.; Kinashi, Y.; Takagaki, M.; Akaboshi, M. Effects of bioreductive agents, tirapazamine and mitomycin C, on quiescent cell populations in solid tumors, evaluated by micronucleus assay. Jpn. J. Cancer Res. 1997, 88, 907-914. [CrossRef] [PubMed]

105. Masunaga, S.; Ono, K.; Hori, H.; Suzuki, M.; Kinashi, Y.; Takagaki, M.; Kasai, S.; Nagasawa, H.; Uto, Y. Change in oxygenation status in intratumour total and quiescent cells following gamma-ray irradiation, tirapazamine administration, cisplatin injection and bleomycin treatment. Br. J. Radiol. 2000, 73, 978-986. [CrossRef]

106. Lambin, P.; Guichard, M.; Chavaudra, N.; Malaise, E.P. The effect of the hypoxic cell drug SR-4233 alone or combined with the ionizing radiations on two human tumor cell lines having different radiosensitivity. Radiother. Oncol. 1992, 24, 201-204. [CrossRef]

107. Dorie, M.J.; Brown, J.M. Tumor-specific, schedule-dependent interaction between tirapazamine (SR 4233) and cisplatin. Cancer Res. 1993, 53, 4633-4636.

108. Rischin, D.; Peters, L.; Hicks, R.; Hughes, P.; Fisher, R.; Hart, R.; Sexton, M.; D'Costa, I.; von Roemeling, R. Phase I trial of concurrent tirapazamine, cisplatin, and radiotherapy in patients with advanced head and neck cancer. J. Clin. Oncol. 2001, 19, 535-542. [CrossRef] [PubMed]

109. Aghajanian, C.; Brown, C.; O’Flaherty, C.; Fleischauer, A.; Curtin, J.; Roemeling, R.; Spriggs, D.R. Phase I study of tirapazamine and cisplatin in patients with recurrent cervical cancer. Gynecol. Oncol. 1997, 67, 127-130. [CrossRef]

110. Craighead, P.S.; Pearcey, R.; Stuart, G. A phase I/II evaluation of tirapazamine administered intravenously concurrent with cisplatin and radiotherapy in women with locally advanced cervical cancer. Int. J. Radiat. Oncol. Biol. Phys. 2000, 48, 791-795. [CrossRef]

111. Le, Q.T.; McCoy, J.; Williamson, S.; Ryu, J.; Gaspar, L.E.; Edelman, M.J.; Dakhil, S.R.; Sides, S.D.; Crowley, J.J.; Gandara, D.R.; et al. Phase I study of tirapazamine plus cisplatin/etoposide and concurrent thoracic radiotherapy in limited-stage small cell lung cancer (S0004): A Southwest Oncology Group study. Clin. Cancer Res. 2004, 10, 5418-5424. [CrossRef]

112. Johnson, C.A.; Kilpatrick, D.; von Roemeling, R.; Langer, C.; Graham, M.A.; Greenslade, D.; Kennedy, G.; Keenan, E.; O’Dwyer, P.J. Phase I trial of tirapazamine in combination with cisplatin in a single dose every 3 weeks in patients with solid tumors. J. Clin. Oncol. 1997, 15, 773-780. [CrossRef] [PubMed]

113. Senan, S.; Rampling, R.; Graham, M.A.; Wilson, P.; Robin, H., Jr.; Eckardt, N.; Lawson, N.; McDonald, A.; von Roemeling, R.; Workman, P.; et al. Phase I and pharmacokinetic study of tirapazamine (SR 4233) administered every three weeks. Clin. Cancer Res. 1997, 3, 31-38.

114. Shulman, L.N.; Buswell, L.; Riese, N.; Doherty, N.; Loeffler, J.S.; von Roemeling, R.W.; Coleman, C.N. Phase I trial of the hypoxic cell cytotoxin tirapazamine with concurrent radiation therapy in the treatment of refractory solid tumors. Int. J. Radiat. Oncol. Biol. Phys. 1999, 44, 349-353. [CrossRef]

115. Bedikian, A.Y.; Legha, S.S.; Eton, O.; Buzaid, A.C.; Papadopoulos, N.; Coates, S.; Simmons, T.; Neefe, J.; von Roemeling, R. Phase II trial of tirapazamine combined with cisplatin in chemotherapy of advanced malignant melanoma. Ann. Oncol. 1997, 8, 363-367. [CrossRef] [PubMed]

116. Rischin, D.; Peters, L.; Fisher, R.; Macann, A.; Denham, J.; Poulsen, M.; Jackson, M.; Kenny, L.; Penniment, M.; Corry, J.; et al. Tirapazamine, Cisplatin, and Radiation versus Fluorouracil, Cisplatin, and Radiation in patients with locally advanced head and neck cancer: A randomized phase II trial of the Trans-Tasman Radiation Oncology Group (TROG 98.02). J. Clin. Oncol. 2005, 23, 79-87. [CrossRef] [PubMed]

117. Lee, D.J.; Trotti, A.; Spencer, S.; Rostock, R.; Fisher, C.; von Roemeling, R.; Harvey, E.; Groves, E. Concurrent tirapazamine and radiotherapy for advanced head and neck carcinomas: A Phase II study. Int. J. Radiat. Oncol. Biol. Phys. 1998, 42, 811-815. [CrossRef]

118. Miller, V.A.; Ng, K.K.; Grant, S.C.; Kindler, H.; Pizzo, B.; Heelan, R.T.; von Roemeling, R.; Kris, M.G. Phase II study of the combination of the novel bioreductive agent, tirapazamine, with cisplatin in patients with advanced non-small-cell lung cancer. Ann. Oncol. 1997, 8, 1269-1271. [CrossRef] [PubMed]

119. Treat, J.; Johnson, E.; Langer, C.; Belani, C.; Haynes, B.; Greenberg, R.; Rodriquez, R.; Drobins, P.; Miller, W., Jr.; Meehan, L.; et al. Tirapazamine with cisplatin in patients with advanced non-small-cell lung cancer: A phase II study. J. Clin. Oncol. 1998, 16, 3524-3527. [CrossRef] [PubMed]

120. Reck, M.; von Pawel, J.; Nimmermann, C.; Groth, G.; Gatzemeier, U. [Phase II-trial of tirapazamine in combination with cisplatin and gemcitabine in patients with advanced non-small-cell-lung-cancer (NSCLC)]. Pneumologie 2004, 58, 845-849. [CrossRef]

121. Maluf, F.C.; Leiser, A.L.; Aghajanian, C.; Sabbatini, P.; Pezzulli, S.; Chi, D.S.; Wolf, J.K.; Levenback, C.; Loh, E.; Spriggs, D.R. Phase II study of tirapazamine plus cisplatin in patients with advanced or recurrent cervical cancer. Int. J. Gynecol. Cancer 2006, 16, 1165-1171. [CrossRef]

122. Le, Q.T.; Moon, J.; Redman, M.; Williamson, S.K.; Lara, P.N., Jr.; Goldberg, Z.; Gaspar, L.E.; Crowley, J.J.; Moore, D.F., Jr.; Gandara, D.R. Phase II study of tirapazamine, cisplatin, and etoposide and concurrent thoracic radiotherapy for limited-stage small-cell lung cancer: SWOG 0222. J. Clin. Oncol. 2009, 27, 3014-3019. [CrossRef] [PubMed] 
123. Del Rowe, J.; Scott, C.; Werner-Wasik, M.; Bahary, J.P.; Curran, W.J.; Urtasun, R.C.; Fisher, B. Single-arm, open-label phase II study of intravenously administered tirapazamine and radiation therapy for glioblastoma multiforme. J. Clin. Oncol. 2000, 18, 1254-1259. [CrossRef]

124. DiSilvestro, P.A.; Ali, S.; Craighead, P.S.; Lucci, J.A.; Lee, Y.C.; Cohn, D.E.; Spirtos, N.M.; Tewari, K.S.; Muller, C.; Gajewski, W.H.; et al. Phase III randomized trial of weekly cisplatin and irradiation versus cisplatin and tirapazamine and irradiation in stages IB2, IIA, IIB, IIIB, and IVA cervical carcinoma limited to the pelvis: A Gynecologic Oncology Group study. J. Clin. Oncol. 2014, 32, 458-464. [CrossRef] [PubMed]

125. Rischin, D.; Peters, L.J.; O’Sullivan, B.; Giralt, J.; Fisher, R.; Yuen, K.; Trotti, A.; Bernier, J.; Bourhis, J.; Ringash, J.; et al. Tirapazamine, cisplatin, and radiation versus cisplatin and radiation for advanced squamous cell carcinoma of the head and neck (TROG 02.02, HeadSTART): A phase III trial of the Trans-Tasman Radiation Oncology Group. J. Clin. Oncol. 2010, 28, 2989-2995. [CrossRef] [PubMed]

126. von Pawel, J.; von Roemeling, R.; Gatzemeier, U.; Boyer, M.; Elisson, L.O.; Clark, P.; Talbot, D.; Rey, A.; Butler, T.W.; Hirsh, V.; et al. Tirapazamine plus cisplatin versus cisplatin in advanced non-small-cell lung cancer: A report of the international CATAPULT I study group. Cisplatin and Tirapazamine in Subjects with Advanced Previously Untreated Non-Small-Cell Lung Tumors. J. Clin. Oncol. 2000, 18, 1351-1359. [CrossRef]

127. Shepherd, F.; Koschel, G.; Von Pawel, J.; Gatzmeier, U.; Van Zandwiyk, N.; Woll, P.; Van Klavren, R.; Krasko, P.; DeSimone, P.; Nicolson, M.; et al. Comparison of Tirazone (Tirapazamine) and cisplatin vs. etoposide and cisplatin in advanced non-small cell lung cancer (NSCLC): Final results of the international Phase III CATAPULT II Trial. Lung Cancer 2000, 29, 28. [CrossRef]

128. Aquino, V.M.; Weitman, S.D.; Winick, N.J.; Blaney, S.; Furman, W.L.; Kepner, J.L.; Bonate, P.; Krailo, M.; Qu, W.; Bernstein, M. Phase I trial of tirapazamine and cyclophosphamide in children with refractory solid tumors: A pediatric oncology group study. J. Clin. Oncol. 2004, 22, 1413-1419. [CrossRef]

129. Mascarenhas, L.; Lyden, E.R.; Breitfeld, P.P.; Walterhouse, D.O.; Donaldson, S.S.; Rodeberg, D.A.; Parham, D.M.; Anderson, J.R.; Meyer, W.H.; Hawkins, D.S. Risk-based treatment for patients with first relapse or progression of rhabdomyosarcoma: A report from the Children's Oncology Group. Cancer 2019, 125, 2602-2609. [CrossRef]

130. Korga, A.; Iwan, M.; Matosiuk, D.; Rzadkowska, M.; Szacon, E.; Humeniuk, E.; Sysa, M.; Ostrowska, M.; Dudka, J. New tirapazamine derivatives protect cardiomyocytes from doxorubicin toxicity. Curr. Issues Pharm. Med. Sci. 2020, 33, 1-5. [CrossRef]

131. Mehibel, M.; Xu, Y.; Li, C.G.; Moon, E.J.; Thakkar, K.N.; Diep, A.N.; Kim, R.K.; Bloomstein, J.D.; Xiao, Y.; Bacal, J.; et al. Eliminating hypoxic tumor cells improves response to PARP inhibitors in homologous recombination-deficient cancer models. J. Clin. Investig. 2021, 131. [CrossRef]

132. Wang, J.; Biedermann, K.A.; Brown, J.M. Repair of DNA and chromosome breaks in cells exposed to SR 4233 under hypoxia or to ionizing radiation. Cancer Res. 1992, 52, 4473-4477. [PubMed]

133. Parveen, I.; Naughton, D.P.; Whish, W.J.; Threadgill, M.D. 2-nitroimidazol-5-ylmethyl as a potential bioreductively activated prodrug system: Reductively triggered release of the PARP inhibitor 5-bromoisoquinolinone. Bioorg. Med. Chem. Lett. 1999, 9, 2031-2036. [CrossRef]

134. Pruijn, F.B.; Patel, K.; Hay, M.P.; Wilson, W.R.; Hicks, K.O. Prediction of Tumour Tissue Diffusion Coefficients of HypoxiaActivated Prodrugs from Physicochemical Parameters. Aust. J. Chem. 2008, 61, 687-693. [CrossRef]

135. Shi, Y.; Gong, M.; Deng, Z.; Liu, H.; Chang, Y.; Yang, Z.; Cai, L. Tirapazamine suppress osteosarcoma cells in part through SLC7A11 mediated ferroptosis. Biochem. Biophys. Res. Commun. 2021, 567, 118-124. [CrossRef] [PubMed]

136. Lei, G.; Zhang, Y.; Koppula, P.; Liu, X.; Zhang, J.; Lin, S.H.; Ajani, J.A.; Xiao, Q.; Liao, Z.; Wang, H.; et al. The role of ferroptosis in ionizing radiation-induced cell death and tumor suppression. Cell Res. 2020, 30, 146-162. [CrossRef] [PubMed]

137. Lin, W.H.; Yeh, S.H.; Yeh, K.H.; Chen, K.W.; Cheng, Y.W.; Su, T.H.; Jao, P.; Ni, L.C.; Chen, P.J.; Chen, D.S. Hypoxia-activated cytotoxic agent tirapazamine enhances hepatic artery ligation-induced killing of liver tumor in HBx transgenic mice. Proc. Natl. Acad. Sci. USA 2016, 113, 11937-11942. [CrossRef]

138. Abi-Jaoudeh, N.; Dayyani, F.; Chen, P.J.; Fernando, D.; Fidelman, N.; Javan, H.; Liang, P.C.; Hwang, J.I.; Imagawa, D.K. Phase I Trial on Arterial Embolization with Hypoxia Activated Tirapazamine for Unresectable Hepatocellular Carcinoma. J. Hepatocell Carcinoma 2021, 8, 421-434. [CrossRef]

139. Semenza, G.L. Targeting HIF-1 for cancer therapy. Nat. Rev. Cancer 2003, 3, 721-732. [CrossRef] [PubMed]

140. Semenza, G.L. Hypoxia-inducible factors in physiology and medicine. Cell 2012, 148, 399-408. [CrossRef] [PubMed]

141. Ivan, M.; Kondo, K.; Yang, H.; Kim, W.; Valiando, J.; Ohh, M.; Salic, A.; Asara, J.M.; Lane, W.S.; Kaelin, W.G., Jr. HIFalpha targeted for VHL-mediated destruction by proline hydroxylation: Implications for O2 sensing. Science 2001, 292, 464-468. [CrossRef]

142. Maxwell, P.H.; Wiesener, M.S.; Chang, G.W.; Clifford, S.C.; Vaux, E.C.; Cockman, M.E.; Wykoff, C.C.; Pugh, C.W.; Maher, E.R.; Ratcliffe, P.J. The tumour suppressor protein VHL targets hypoxia-inducible factors for oxygen-dependent proteolysis. Nature 1999, 399, 271-275. [CrossRef]

143. Berra, E.; Benizri, E.; Ginouves, A.; Volmat, V.; Roux, D.; Pouyssegur, J. HIF prolyl-hydroxylase 2 is the key oxygen sensor setting low steady-state levels of HIF-1alpha in normoxia. EMBO J. 2003, 22, 4082-4090. [CrossRef]

144. Arany, Z.; Huang, L.E.; Eckner, R.; Bhattacharya, S.; Jiang, C.; Goldberg, M.A.; Bunn, H.F.; Livingston, D.M. An essential role for p300/CBP in the cellular response to hypoxia. Proc. Natl. Acad. Sci. USA 1996, 93, 12969-12973. [CrossRef] [PubMed]

145. Moon, E.J.; Brizel, D.M.; Chi, J.T.; Dewhirst, M.W. The potential role of intrinsic hypoxia markers as prognostic variables in cancer. Antioxid. Redox Signal. 2007, 9, 1237-1294. [CrossRef] 
146. Semenza, G.L. Involvement of oxygen-sensing pathways in physiologic and pathologic erythropoiesis. Blood 2009, 114, 2015-2019. [CrossRef] [PubMed]

147. Lee, P.; Chandel, N.S.; Simon, M.C. Cellular adaptation to hypoxia through hypoxia inducible factors and beyond. Nat. Rev. Mol. Cell Biol. 2020, 21, 268-283. [CrossRef]

148. Moeller, B.J.; Cao, Y.; Li, C.Y.; Dewhirst, M.W. Radiation activates HIF-1 to regulate vascular radiosensitivity in tumors: Role of reoxygenation, free radicals, and stress granules. Cancer Cell 2004, 5, 429-441. [CrossRef]

149. Harada, H.; Kizaka-Kondoh, S.; Li, G.; Itasaka, S.; Shibuya, K.; Inoue, M.; Hiraoka, M. Significance of HIF-1-active cells in angiogenesis and radioresistance. Oncogene 2007, 26, 7508-7516. [CrossRef] [PubMed]

150. Yang, Z.F.; Poon, R.T.; To, J.; Ho, D.W.; Fan, S.T. The potential role of hypoxia inducible factor 1alpha in tumor progression after hypoxia and chemotherapy in hepatocellular carcinoma. Cancer Res. 2004, 64, 5496-5503. [CrossRef] [PubMed]

151. Levina, V.; Su, Y.; Nolen, B.; Liu, X.; Gordin, Y.; Lee, M.; Lokshin, A.; Gorelik, E. Chemotherapeutic drugs and human tumor cells cytokine network. Int. J. Cancer 2008, 123, 2031-2040. [CrossRef]

152. Viola, R.J.; Provenzale, J.M.; Li, F.; Li, C.Y.; Yuan, H.; Tashjian, J.; Dewhirst, M.W. In vivo bioluminescence imaging monitoring of hypoxia-inducible factor 1alpha, a promoter that protects cells, in response to chemotherapy. AJR Am. J. Roentgenol. 2008, 191, 1779-1784. [CrossRef] [PubMed]

153. Befani, C.D.; Vlachostergios, P.J.; Hatzidaki, E.; Patrikidou, A.; Bonanou, S.; Simos, G.; Papandreou, C.N.; Liakos, P. Bortezomib represses HIF-1alpha protein expression and nuclear accumulation by inhibiting both PI3K/Akt/TOR and MAPK pathways in prostate cancer cells. J. Mol. Med. 2012, 90, 45-54. [CrossRef]

154. Bertozzi, D.; Marinello, J.; Manzo, S.G.; Fornari, F.; Gramantieri, L.; Capranico, G. The natural inhibitor of DNA topoisomerase I, camptothecin, modulates HIF-1alpha activity by changing miR expression patterns in human cancer cells. Mol. Cancer Ther. 2014, 13, 239-248. [CrossRef] [PubMed]

155. Fallah, J.; Rini, B.I. HIF Inhibitors: Status of Current Clinical Development. Curr. Oncol. Rep. 2019, 21, 6. [CrossRef] [PubMed]

156. Semenza, G.L. Pharmacologic Targeting of Hypoxia-Inducible Factors. Annu. Rev. Pharmacol. Toxicol. 2019, 59, 379-403. [CrossRef]

157. Soni, S.; Padwad, Y.S. HIF-1 in cancer therapy: Two decade long story of a transcription factor. Acta Oncol. 2017, 56, 503-515. [CrossRef] [PubMed]

158. Wigerup, C.; Pahlman, S.; Bexell, D. Therapeutic targeting of hypoxia and hypoxia-inducible factors in cancer. Pharmacol. Ther. 2016, 164, 152-169. [CrossRef]

159. Shirai, Y.; Chow, C.C.T.; Kambe, G.; Suwa, T.; Kobayashi, M.; Takahashi, I.; Harada, H.; Nam, J.M. An Overview of the Recent Development of Anticancer Agents Targeting the HIF-1 Transcription Factor. Cancers 2021, 13, 2813. [CrossRef] [PubMed]

160. Wallace, E.M.; Rizzi, J.P.; Han, G.; Wehn, P.M.; Cao, Z.; Du, X.; Cheng, T.; Czerwinski, R.M.; Dixon, D.D.; Goggin, B.S.; et al. A Small-Molecule Antagonist of HIF2alpha Is Efficacious in Preclinical Models of Renal Cell Carcinoma. Cancer Res. 2016, 76, 5491-5500. [CrossRef] [PubMed]

161. Chen, W.; Hill, H.; Christie, A.; Kim, M.S.; Holloman, E.; Pavia-Jimenez, A.; Homayoun, F.; Ma, Y.; Patel, N.; Yell, P.; et al. Targeting renal cell carcinoma with a HIF-2 antagonist. Nature 2016, 539, 112-117. [CrossRef]

162. Cho, H.; Du, X.; Rizzi, J.P.; Liberzon, E.; Chakraborty, A.A.; Gao, W.; Carvo, I.; Signoretti, S.; Bruick, R.K.; Josey, J.A.; et al. On-target efficacy of a HIF-2alpha antagonist in preclinical kidney cancer models. Nature 2016, 539, 107-111. [CrossRef] [PubMed]

163. Renfrow, J.J.; Soike, M.H.; West, J.L.; Ramkissoon, S.H.; Metheny-Barlow, L.; Mott, R.T.; Kittel, C.A.; D’Agostino, R.B., Jr.; Tatter, S.B.; Laxton, A.W.; et al. Attenuating hypoxia driven malignant behavior in glioblastoma with a novel hypoxia-inducible factor 2 alpha inhibitor. Sci. Rep. 2020, 10, 15195. [CrossRef] [PubMed]

164. Courtney, K.D.; Infante, J.R.; Lam, E.T.; Figlin, R.A.; Rini, B.I.; Brugarolas, J.; Zojwalla, N.J.; Lowe, A.M.; Wang, K.; Wallace, E.M.; et al. Phase I Dose-Escalation Trial of PT2385, a First-in-Class Hypoxia-Inducible Factor-2alpha Antagonist in Patients with Previously Treated Advanced Clear Cell Renal Cell Carcinoma. J. Clin. Oncol. 2018, 36, 867-874. [CrossRef] [PubMed]

165. Courtney, K.D.; Ma, Y.; Diaz de Leon, A.; Christie, A.; Xie, Z.; Woolford, L.; Singla, N.; Joyce, A.; Hill, H.; Madhuranthakam, A.J.; et al. HIF-2 Complex Dissociation, Target Inhibition, and Acquired Resistance with PT2385, a First-in-Class HIF-2 Inhibitor, in Patients with Clear Cell Renal Cell Carcinoma. Clin. Cancer Res. 2020, 26, 793-803. [CrossRef] [PubMed]

166. Choueiri, T.K.; Albiges, L.; Fan, L.; Perini, R.F.; Zojwalla, N.J.; Powles, T.; Rini, B.I. Phase III study of the hypoxia-inducible factor $2 \alpha$ (HIF-2 $\alpha$ ) inhibitor MK-6482 versus everolimus in previously treated patients with advanced clear cell renal cell carcinoma (ccRCC). J. Clin. Oncol. 2020, 38, TPS5094. [CrossRef]

167. Xu, R.; Wang, K.; Rizzi, J.P.; Huang, H.; Grina, J.A.; Schlachter, S.T.; Wang, B.; Wehn, P.M.; Yang, H.; Dixon, D.D.; et al. 3[(1S,2S,3R)-2,3-Difluoro-1-hydroxy-7-methylsulfonylindan-4-yl]oxy-5-fluorobenzo nitrile (PT2977), a Hypoxia-Inducible Factor 2alpha (HIF-2alpha) Inhibitor for the Treatment of Clear Cell Renal Cell Carcinoma. J. Med. Chem. 2019, 62, 6876-6893. [CrossRef]

168. Ashton, T.M.; McKenna, W.G.; Kunz-Schughart, L.A.; Higgins, G.S. Oxidative Phosphorylation as an Emerging Target in Cancer Therapy. Clin. Cancer Res. 2018, 24, 2482-2490. [CrossRef] [PubMed]

169. Moeller, B.J.; Richardson, R.A.; Dewhirst, M.W. Hypoxia and radiotherapy: Opportunities for improved outcomes in cancer treatment. Cancer Metastasis Rev. 2007, 26, 241-248. [CrossRef]

170. Secomb, T.W.; Hsu, R.; Ong, E.T.; Gross, J.F.; Dewhirst, M.W. Analysis of the Effects of Oxygen Supply and Demand on Hypoxic Fraction in Tumors. Acta Oncol. 1995, 34, 313-316. [CrossRef] 
171. Koritzinsky, M. Metformin: A Novel Biological Modifier of Tumor Response to Radiation Therapy. Int. J. Radiat. Oncol. Biol. Phys. 2015, 93, 454-464. [CrossRef] [PubMed]

172. Evans, J.M.M.; Donnelly, L.A.; Emslie-Smith, A.M.; Alessi, D.R.; Morris, A.D. Metformin and reduced risk of cancer in diabetic patients. BMJ 2005, 330, 1304-1305. [CrossRef] [PubMed]

173. Bowker, S.L.; Majumdar, S.R.; Veugelers, P.; Johnson, J.A. Increased Cancer-Related Mortality for Patients with Type 2 Diabetes Who Use Sulfonylureas or Insulin. J. Diabetes Care 2006, 29, 254-258. [CrossRef]

174. Pernicova, I.; Korbonits, M. Metformin-Mode of action and clinical implications for diabetes and cancer. Nat. Rev. Endocrinol. 2014, 10, 143-156. [CrossRef] [PubMed]

175. Kelly, C.J.; Hussien, K.; Fokas, E.; Kannan, P.; Shipley, R.J.; Ashton, T.M.; Stratford, M.; Pearson, N.; Muschel, R.J. Regulation of $\mathrm{O} 2$ consumption by the PI3K and mTOR pathways contributes to tumor hypoxia. Radiother. Oncol. 2014, 111, 72-80. [CrossRef]

176. Howell, J.J.; Hellberg, K.; Turner, M.; Talbott, G.; Kolar, M.J.; Ross, D.S.; Hoxhaj, G.; Saghatelian, A.; Shaw, R.J.; Manning, B.D. Metformin Inhibits Hepatic mTORC1 Signaling via Dose-Dependent Mechanisms Involving AMPK and the TSC Complex. Cell Metab. 2017, 25, 463-471. [CrossRef] [PubMed]

177. Ashton, T.M.; Fokas, E.; Kunz-Schughart, L.A.; Folkes, L.K.; Anbalagan, S.; Huether, M.; Kelly, C.J.; Pirovano, G.; Buffa, F.M.; Hammond, E.M.; et al. The anti-malarial atovaquone increases radiosensitivity by alleviating tumour hypoxia. Nat. Commun. 2016, 7, 12308. [CrossRef]

178. Chowdhury, S.; Yung, E.; Pintilie, M.; Muaddi, H.; Chaib, S.; Yeung, M.; Fusciello, M.; Sykes, J.; Pitcher, B.; Hagenkort, A.; et al. MATE2 Expression Is Associated with Cancer Cell Response to Metformin. PLoS ONE 2016, 11, e0165214. [CrossRef]

179. Wheaton, W.W.; Weinberg, S.E.; Hamanaka, R.B.; Soberanes, S.; Sullivan, L.B.; Anso, E.; Glasauer, A.; Dufour, E.; Mutlu, G.M.; Budigner, G.S.; et al. Metformin inhibits mitochondrial complex I of cancer cells to reduce tumorigenesis. Elife 2014, 3 , e02242. [CrossRef]

180. Zannella, V.E.; Dal Pra, A.; Muaddi, H.; McKee, T.D.; Stapleton, S.; Sykes, J.; Glicksman, R.; Chaib, S.; Zamiara, P.; Milosevic, M.; et al. Reprogramming Metabolism with Metformin Improves Tumor Oxygenation and Radiotherapy Response. Clin. Cancer Res. 2013, 19, 6741-6750. [CrossRef] [PubMed]

181. Brown, S.L.; Kolozsvary, A.; Isrow, D.M.; Al Feghali, K.; Lapanowski, K.; Jenrow, K.A.; Kim, J.H. A Novel Mechanism of High Dose Radiation Sensitization by Metformin. Front. Oncol. 2019, 9, 247. [CrossRef]

182. de Mey, S.; Jiang, H.; Corbet, C.; Wang, H.; Dufait, I.; Law, K.; Bastien, E.; Verovski, V.; Gevaert, T.; Feron, O.; et al. Antidiabetic Biguanides Radiosensitize Hypoxic Colorectal Cancer Cells Through a Decrease in Oxygen Consumption. Front. Pharmacol. 2018, 9, 1073. [CrossRef]

183. Birsoy, K.; Possemato, R.; Lorbeer, F.K.; Bayraktar, E.C.; Thiru, P.; Yucel, B.; Wang, T.; Chen, W.W.; Clish, C.B.; Sabatini, D.M. Metabolic determinants of cancer cell sensitivity to glucose limitation and biguanides. Nature 2014, 508, 108-112. [CrossRef]

184. Yuan, P.; Ito, K.; Perez-Lorenzo, R.; Del Guzzo, C.; Lee, J.H.; Shen, C.H.; Bosenberg, M.W.; McMahon, M.; Cantley, L.C.; Zheng, B. Phenformin enhances the therapeutic benefit of BRAF(V600E) inhibition in melanoma. Proc. Natl. Acad. Sci. USA 2013, 110, 18226-18231. [CrossRef] [PubMed]

185. Shackelford, D.B.; Abt, E.; Gerken, L.; Vasquez, D.S.; Seki, A.; Leblanc, M.; Wei, L.; Fishbein, M.C.; Czernin, J.; Mischel, P.S.; et al. LKB1 inactivation dictates therapeutic response of non-small cell lung cancer to the metabolism drug phenformin. Cancer Cell 2013, 23, 143-158. [CrossRef]

186. Appleyard, M.V.; Murray, K.E.; Coates, P.J.; Wullschleger, S.; Bray, S.E.; Kernohan, N.M.; Fleming, S.; Alessi, D.R.; Thompson, A.M. Phenformin as prophylaxis and therapy in breast cancer xenografts. Br. J. Cancer 2012, 106, 1117-1122. [CrossRef] [PubMed]

187. Masoud, R.; Reyes-Castellanos, G.; Lac, S.; Garcia, J.; Dou, S.; Shintu, L.; Abdel Hadi, N.; Gicquel, T.; El Kaoutari, A.; Diémé, B.; et al. Targeting Mitochondrial Complex I Overcomes Chemoresistance in High OXPHOS Pancreatic Cancer. Cell Rep. Med. 2020, 1, 100143. [CrossRef]

188. Ellinghaus, P.; Heisler, I.; Unterschemmann, K.; Haerter, M.; Beck, H.; Greschat, S.; Ehrmann, A.; Summer, H.; Flamme, I.; Oehme, F; et al. BAY 87-2243, a highly potent and selective inhibitor of hypoxia-induced gene activation has antitumor activities by inhibition of mitochondrial complex I. Cancer Med. 2013, 2, 611-624. [CrossRef]

189. Zhang, L.; Zhang, J.; Ye, Z.; Townsend, D.M.; Tew, K.D. Pharmacology of ME-344, a novel cytotoxic isoflavone. Adv. Cancer Res. 2019, 142, 187-207. [CrossRef]

190. Lissanu Deribe, Y.; Sun, Y.; Terranova, C.; Khan, F.; Martinez-Ledesma, J.; Gay, J.; Gao, G.; Mullinax, R.A.; Khor, T.; Feng, N.; et al. Mutations in the SWI/SNF complex induce a targetable dependence on oxidative phosphorylation in lung cancer. Nat. Med. 2018, 24, 1047-1057. [CrossRef]

191. Molina, J.R.; Sun, Y.; Protopopova, M.; Gera, S.; Bandi, M.; Bristow, C.; McAfoos, T.; Morlacchi, P.; Ackroyd, J.; Agip, A.A.; et al. An inhibitor of oxidative phosphorylation exploits cancer vulnerability. Nat. Med. 2018, 24, 1036-1046. [CrossRef] [PubMed] 
192. Diamond, J.R.; Goff, B.; Forster, M.D.; Bendell, J.C.; Britten, C.D.; Gordon, M.S.; Gabra, H.; Waterhouse, D.M.; Poole, M.; Ross Camidge, D.; et al. Phase Ib study of the mitochondrial inhibitor ME-344 plus topotecan in patients with previously treated, locally advanced or metastatic small cell lung, ovarian and cervical cancers. Investig. New Drugs 2017, 35, 627-633. [CrossRef] [PubMed]

193. Chen, P.H.; Wu, J.; Ding, C.C.; Lin, C.C.; Pan, S.; Bossa, N.; Xu, Y.; Yang, W.H.; Mathey-Prevot, B.; Chi, J.T. Kinome screen of ferroptosis reveals a novel role of ATM in regulating iron metabolism. Cell Death Differ. 2020, 27, 1008-1022. [CrossRef] [PubMed]

194. Diepart, C.; Karroum, O.; Magat, J.; Feron, O.; Verrax, J.; Calderon, P.B.; Grégoire, V.; Leveque, P.; Stockis, J.; Dauguet, N.; et al. Arsenic Trioxide Treatment Decreases the Oxygen Consumption Rate of Tumor Cells and Radiosensitizes Solid Tumors. Cancer Res. 2012, 72, 482-490. [CrossRef] [PubMed] 